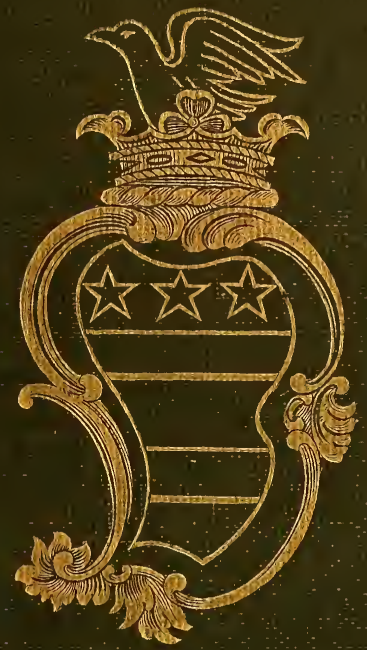

THR E T TPES OF WASHINGTON

PORIRAITS 

Hiss. Bevel

willa the complements of

Clearer le murmur,

OF THIS BOOK TWO HUNDRED AND

TWENTY-FIVE COPIES HAVE BEEN

PRINTED ON VAN GELLER

HANDMADE PAPER 



\section{THREE TYPES OF WASHINGTON PORTRAITS}





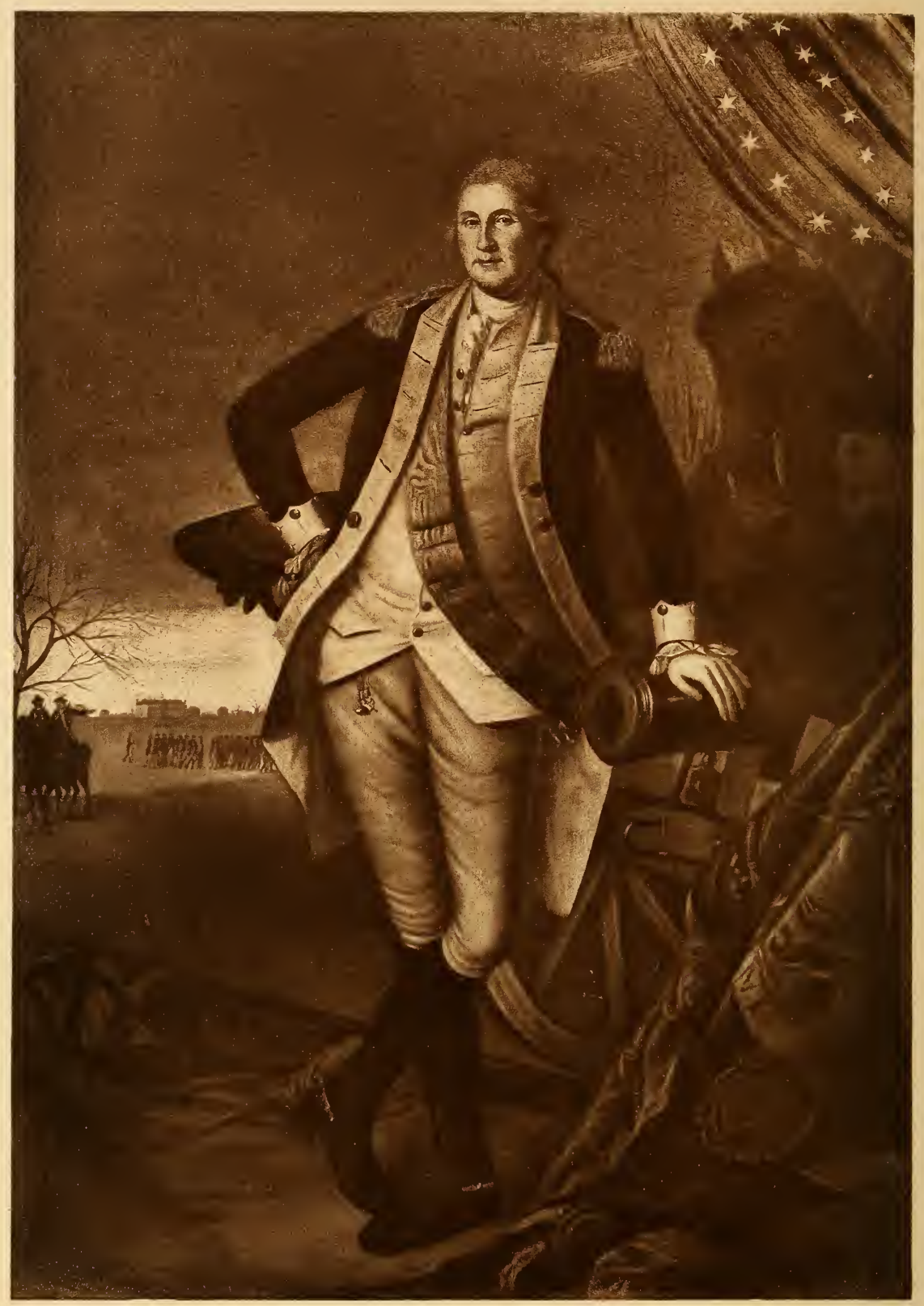

GENERAL WASHINGTON

PAINTED BY CHARLES WILLSON PEALE

ORIGINAL OWNER

JOSEPH WILSON

OF PHILADELPHIA AND DUBLIN
PRESENT OWNER CHARLES A. MUNN 


\title{
THREE TYPES OF WASHINGTON PORTRAITS
}

\author{
JOHN TRUMBULL \\ CHARLES WILLSON PEALE \\ GILBERT STUART \\ B Y \\ CHARLES ALLEN MUNN
}

NEW YORK

PRIVATELY PRINTED

MCMVIII

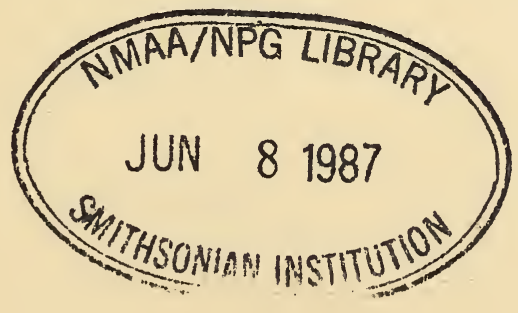


COPYRIGHT, I9O8

BY CHARLES A. MUNN 


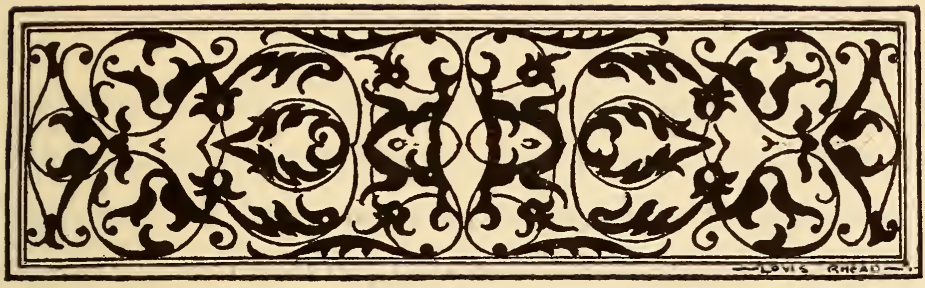

\section{FOREWORD}

DROM the time Washington took command of the army at Cambridge a very general public interest was aroused in the personal appearance of the Commander-inChief. The many engraved portraits of Washington which were published during his lifetime bear upon their face the evidence of their own identity and genuineness. Not so, however, the oil portraits which have as a rule no date or signature; their authenticity rests partly upon their inherent quality but more particularly upon their history or pedigree. Most of the original portraits of Washington were painted from one hundred and ten to one hundred and twenty-five years ago, and, as in so long a period documentary evidence of authenticity is in the case of most of the contemporary portraits entirely lost or rests vii 
upon very feeble family tradition, it is desirable to take every precaution to preserve jealously the pedigrees of such portraits as are beyond dispute. Letters or documents relating to such a precious heirloom as an authentic contemporary portrait of Washington should be safe-guarded in every possible way. Such documents are always in danger of being lost or destroyed, but there is one method, reproduction by printing, which is more sure and certain than preservation even in a safe deposit vault. Although this little book is circulated only among a small circle of friends, it is hoped that the printing of these records may be the means of preserving in perpetuity the history and the pedigree of the three portraits illustrated within these covers, which represent Washington as he appeared at two very different periods of his life - Washington, the General, and Washington, the President.

C. A. M.

The Terraces, Llewellyn Park, Orange, N. J. 


\section{ILLUSTRATIONS}

FACING PAGE

General Washington . . . . . . Title

Painted by Charles Willson Peale.

Original owner Joseph Wilson of Philadelphia and Dublin. Present owner Charles A. Munn.

John TRUMBulL

From a portrait by Gilbert Stuart. Property of Mrs. William Forbes Morgan.

Portrait of General Washington

Painted by John Trumbull-I 780 .

Original owner M. de Neufville of Amsterdam. Present owner, Charles A. Munn.

George Washington

6

Engraved by Valentine Green-I 781 .

After the portrait by Trumbull. The earliest genuine portrait of Washington published in Europe.

WASHINGTON

After the Trumbull portrait.

With fictitious tropical landscape.

Early Chintz Bed Curtain . . . : 8

Allegorical composition with figure of Washington after the Trumbull portrait.

Early Lacruered Tea Tray

"The Signing of the Declaration of Independence."

From an unknown composition, probably by Trumbull. 


\section{ILLUSTRATIONS}

Washington at the Battle of PrinceTON

Painted by Charles Willson Peale-I 783 .

Original owner Princeton College. Present owner Princeton University.

Earliest Authentic Engraved Portrait of General Washington . $\quad 28$

Drawn and engraved by C. W. Peale- 7778 .

Charles Willson Peale • • • . 3 I From the National Portrait Gallery.

Charles Willson Peale Certificate 33 Signed by Benjamin Franklin.

Letters Patent Appointing Joseph WiLson Consul at Dublin-i794 • 40

President Washington . . . . 43

Painted by Gilbert Stuart - I 795 .

Original owner Mr. Scott of Lancaster, Pa. Present owner Charles A. Munn.

George Washington •. . . . 48 Engraved by E. Savage-I 801 .

After the Lansdowne portrait.

Ivory Miniature of Gilbert Stuart 52

Painted by Miss Goodridge.

Owned by the Metropolitan Museum of Art.

Miniature of Washington . . . 60 By Robert Field.

Presented to Tobias Lear by Mrs. Washington.

Owned by Charles A. Munn. 



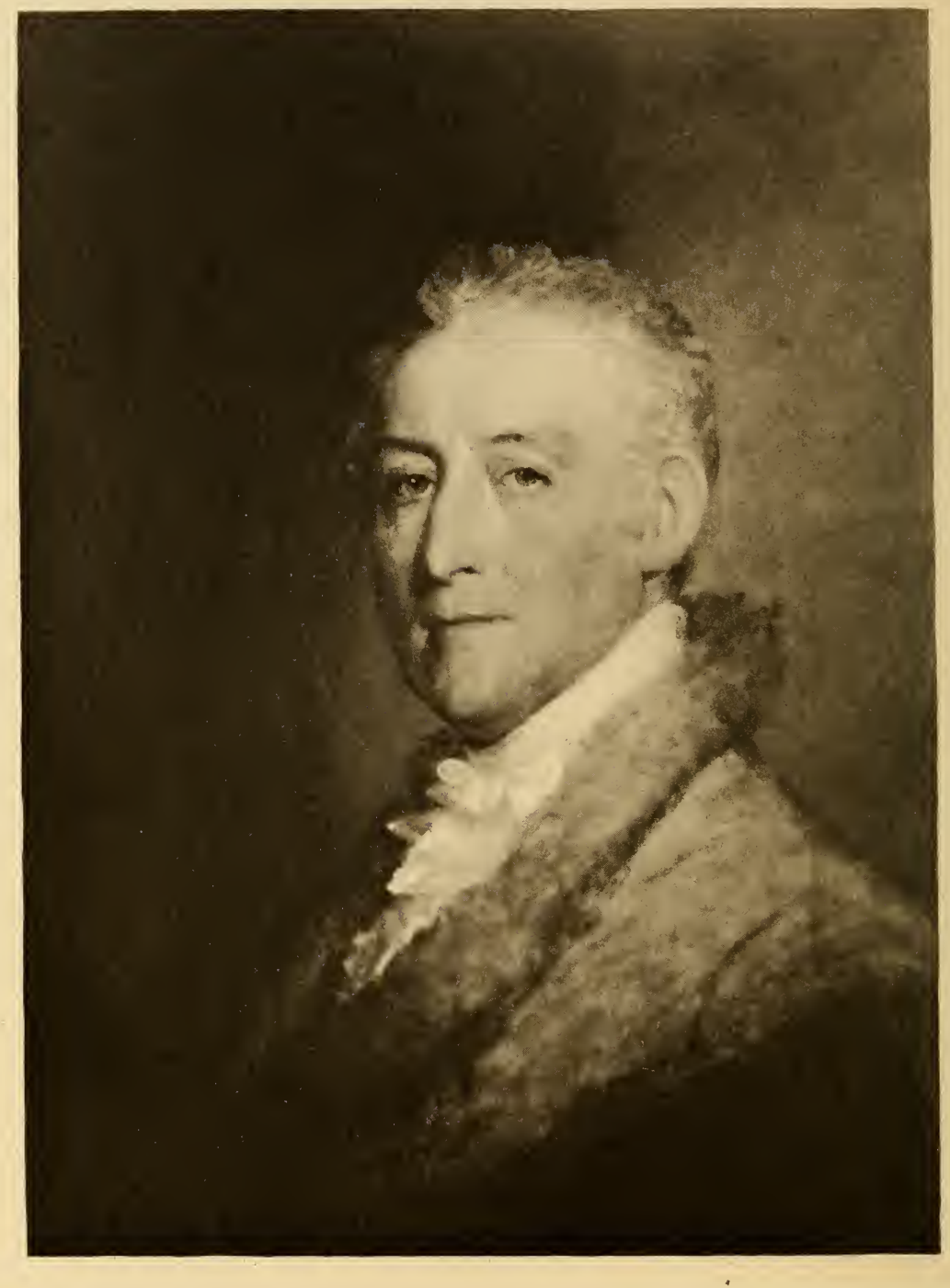

JOHN TRUMBULL

FROM A PORTRAIT BY GILBERT STUART

PROPERTY OF MRS. WILLIAM FORBES MORGAN 


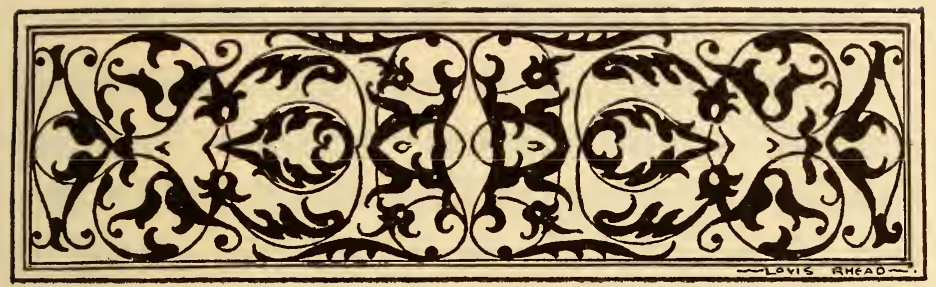

THE JOHN TRUMBULL TYPE

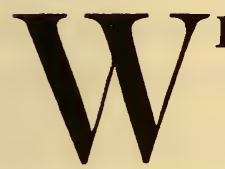

HEN the War of the Revolution broke out there was in Europe a very general interest in the man who was chosen as the Commander-in-Chief of the American army. The age was one when the love of portraiture was at its zenith, and the beautiful mezzotints which we know so well and which command to-day such enormous prices were being published and sold for a few shillings. The publisher in those days was generally a man of affairs and eager to turn the nimble shilling. Of course, no portrait of Washington had been sent to Europe; in fact, no engraved portrait of the great leader existed in this country, nor was one published here until three years after the war began. Such a little obstacle as this, however, did not stand in the way of gratifying the public demand. 
In September, I775, there was published in London a very curious mezzotint, entitled "George Washington, Esq., General and Commander-in-Chief of the Continental Army in America. Done from an original, drawn from life by Alexander Campbell, of Williamsburgh, in Virginia." This portrait which, of course, was purely fictitious, may be found in every collection of Washington portraits. It was at one time considered a great rarity. It certainly is a great curiosity. It is frequently offered at public sale, and its great popularity at the time of its publication is proved by the fact that it is no longer a rarity, except when found in very fine condition. It represents Washington mounted on a charger, galloping at full speed and waving a drawn sword in his hand, while a bloody battle is being waged in the background. One of these prints was presented to Mrs. Washington by Joseph Reed, at one time President of Congress. Washington, in acknowledging the receipt of the print, wrote in January, 1776 , as follows: "Mr. Campbell, whom I never saw to my knowledge, has made a very formidable figure of the Commander-in-Chief, giving him a sufficient portion of terror in his countenance." In view of the shameless manner in which the public had 
been imposed upon by this forgery, it is hardly any wonder that a genuine portrait of Washington, engraved by one of the great master-hands of the art of engraving in mezzotinto, should have been hailed with delight by the collectors of those days.

The print in question is a large folio, after the painting by John Trumbull. Trumbull, who had served at the outbreak of the war as aidede-camp to Washington, had had frequent opportunities of studying the features of the man he greatly admired.* In May, I780, he sailed for the other side, having previously resigned his commission in the army in order to make a serious study of the art to which he devoted his life. On arriving in London he presented a letter of introduction from Dr. Franklin to Benjamin West, and soon began the serious study of art under him who was at that time considered a great master, a charming gentleman, and one ever wel-

* In an Orderly Book of the Commander-in-Chief, containing the official orders issued from the camp at Cambridge, is found the following:

“General Orders Head Quarters, July $27^{\text {th }}$, 1775

Parole Bedford, Countersign Guilford

John Trumbull Esq' being appointed Aid de Camp to his

Excellency the Commander in Chief, is to be obeyed as such." 
come at court. By a curious coincidence, Gilbert Stuart was pursuing his studies under West at the same time. Before many months had elasped, however, an untoward incident occurred which, for the time being, resulted in Trumbull severing his connection with his master and fleeing England. He was arrested and thrown into prison as a suspect, during the period immediately following the arrest and execution of the unfortunate André. He languished in prison for some months, but was finally released through the good offices of his friend and patron, Benjamin West, who interceded with the King in his behalf. No proof could be brought against him; the only crime he had committed was being the son of Jonathan Trumbull, the patriot Governor of Connecticut, and of having served in the Continental army. On obtaining his release he was not long in leaving the shores where he had been treated so inhospitably.

When Trumbull arrived on the Continent he decided to take up his residence for a short time in Amsterdam, and upon his arrival there he found important papers awaiting him; in short, he found a packet from his father, Governor Trumbull, containing authority and instructions to negotiate a loan in Holland for the State of 



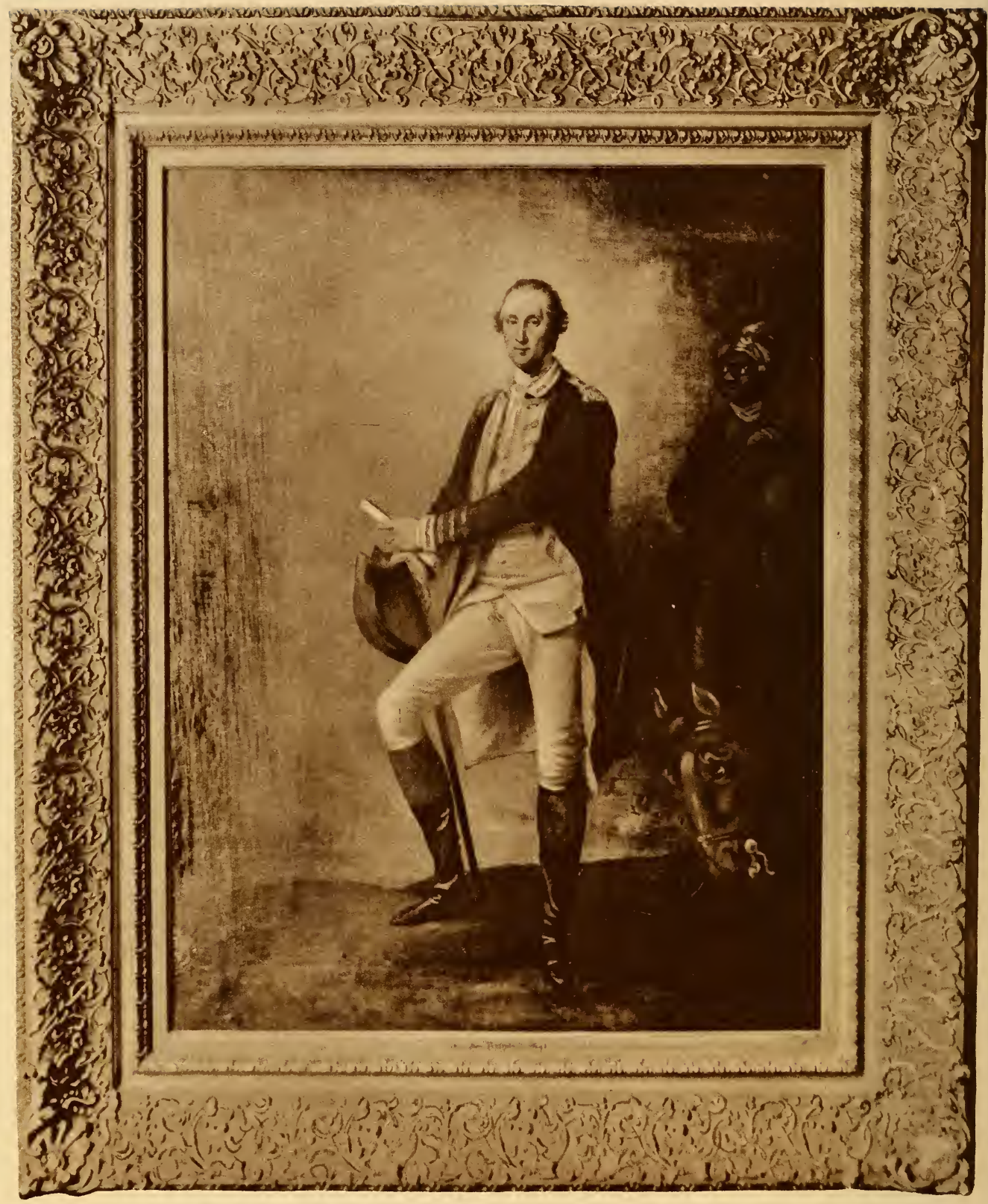

PORTRAIT OF GENERAL WASHINGTON

PAINTED BY JOHN TRUMBULL-I 780

ORIGINAL OWNER

PRESENT OWNER

M. DE NEUfVille

CHARLES A. MUNN

OF AMSTERDAM 
Connecticut. He at once repaired to the banking house of De Neufville \& Son, the members of which, he says, "are unquestionably the most worthy of the confidence of the State, from their knowledge, connections and real attachment for America. He was warmly received by Mr. De Neufville." He writes, "Immediately on my arrival here Mr. De Neufville invited me to his house, where I am at present very hospitably and elegantly entertained."

The portrait of Washington, illustrated in connection with this chapter, may have been presented to Mr. De Neufville in consideration of many favors received, but it must have been conveyed to him prior to Trumbull's arrival in Amsterdam. In a letter to his father, Governor Trumbull, he writes: "I have received from him $£$ roo, which has brought me off without the necessity of being under obligations to any persons in England." As Trumbull had only the most limited resources, save what he could raise by the exercise of his profession, it seems possible that this sum may have been in payment for the portrait of Washington. No mention is made of the portrait in his correspondence or papers, and conjecture alone can solve the problem of how the portrait came into the possession 
of the banker. As a matter of historic interest there will be found on another page a reproduction of the famous engraving, by Valentine Green, and the title under the engraving is given here in full :

\section{GENERAL WASHINGTON}

Painted by J. Trumbull, Esq., of Connecticut, 1780. Engraved by V. Green, Mezzotinto Engraver to His Majesty and to the Elector Palatin. Engraved from the original picture in the possession of M. De Neufville, of Amsterdam. Publish'd by Appointmt of M. De Neufville, Janry ${ }^{1} 5^{\text {th, }} \mathbf{1 7}_{7} \mathrm{r}$, by V. Green, N. 29, Newman Street, Oxford Street, London.

From the above it would appear that the portrait must have been sold to the banker De Neufville before Trumbull left London. Trumbull was released from prison in June, I880. He remained in London a few days only, and then set out for the Continent. In his autobiography he mentions having met Mr. De Neufville, the son and junior partner of the house, in London. It is probable that the portrait was sold to him at that time, and it is further probable that the portrait was not sent to Amsterdam until after Trumbull had left London. He remained in Amsterdam until August, I 78 I, when he sailed for America. The portrait, however, must have remained in the hands of Valentine Green until approximately the date of its publication, which was January $15,178 \mathrm{I}$. Its size is $28 \mathrm{x}_{3} 6$ inches. 


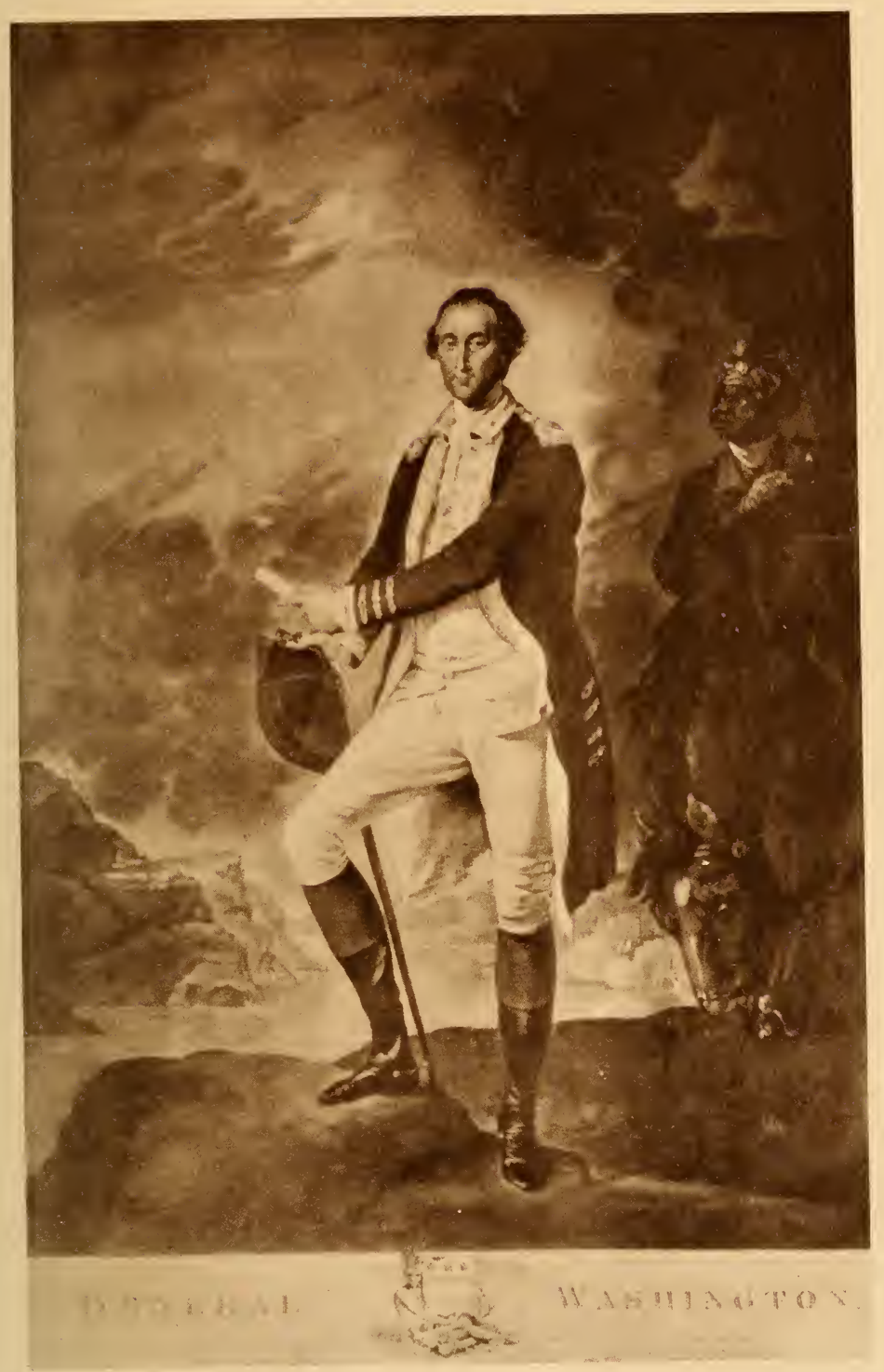

GEORGE WASHINGTON

ENGRAVED BY VALENTINE GREEN-I78I-AFTER THE PORTRAIT BY TRUMBULL

THE EARLIEST GENUINE PORTRAIT OF WASHINGTON PUBLISHED IN EUROPE 



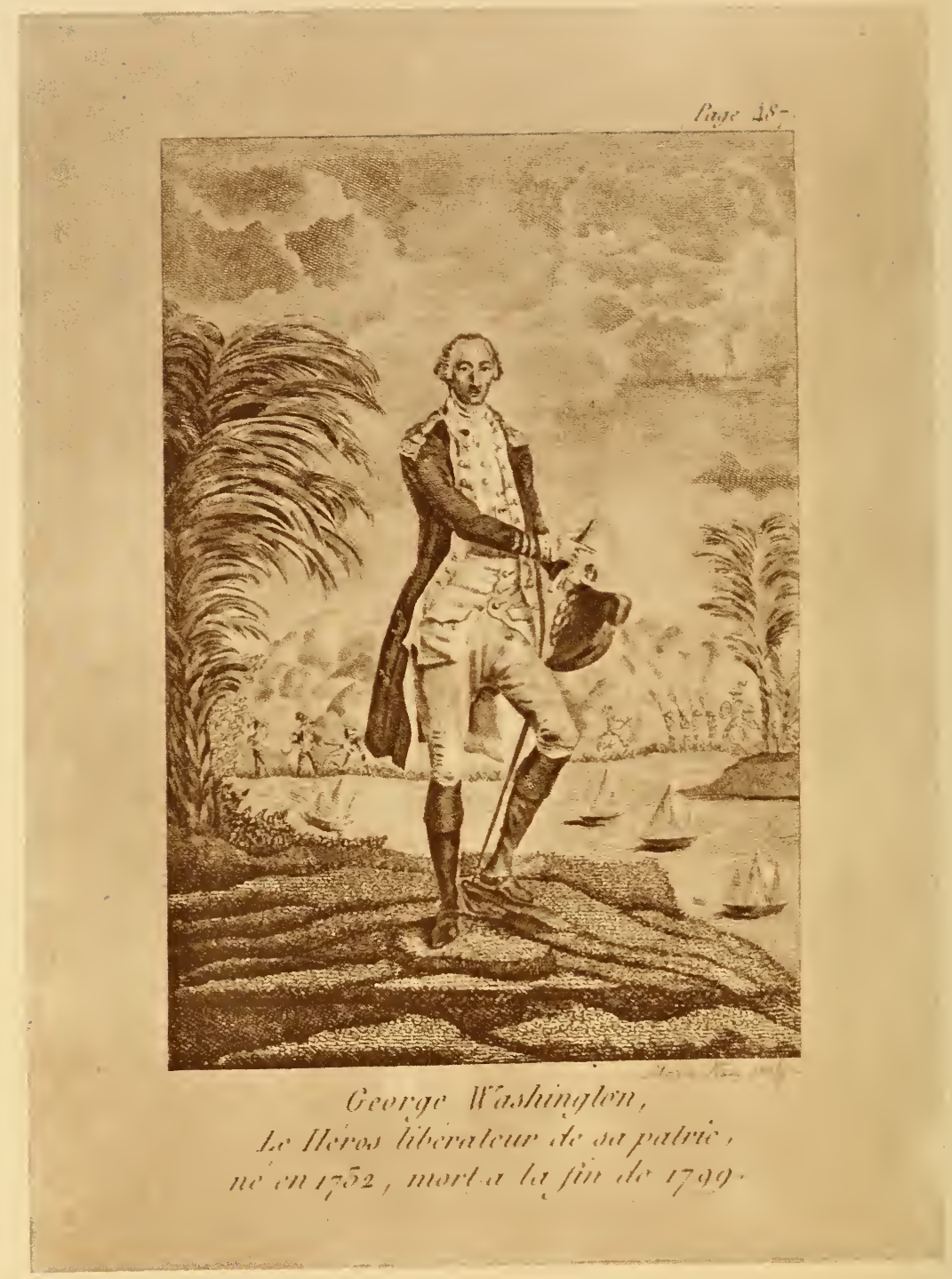

\section{WASHINGTON}

AFTER THE TRUMBULL PORTRAIT

WITH FICTITIOUS TROPICAL LANDSCAPE 


\section{JOHN TRUMBULL}

The popularity of the portrait was very great. It was the first authentic portrait of Washington that had been published in Europe, and copies of it were soon issued in France and elsewhere. One of the most attractive of these reproductions was published in Brussels, in $178 \mathrm{I}$, in the "Essais Historiques et Politiques sur les Anglo-Americains" par M. Hilliard d'Auberteuil. An enlarged edition (folio) of this same attractive work was published in the following year, the print having been enlarged to fit the increased size of the book, by the addition of an attractive border.

A curious corruption of this same portrait was published in "Beautés de l'Histoire des EtatsUnis," Par J. B. Nougaut, Paris, I 8 I 7. It was engraved by Maria Misa. The figure of Washington is the same, but the Commander-in-Chief is standing on a promontory surrounded by gigantic tropical trees and with a fleet of diminutive war ships occupying the bay in the background.

The persistency with which this figure of Washington appears in the various engravings and prints of the period is shown in a contemporary bed curtain which is reproduced in an accompanying engraving. It was the custom to provide the old mahogany four-posters of our forefathers with suitable bed hangings, and in the 
curtain shown the figure of Washington is an exact reproduction of the Trumbull portrait. This composition is an exceedingly interesting one. An attractive female figure, bearing a palm in one hand and treading disdainfully upon the shield of Great Britain, seems to be approaching the General with the view of whispering some word of encouragement or flattery in his ear. In her right hand she carries a medallion embellished with the portraits of Adams and Laurens. An angel who is floating in the air above is in the act of crowning the Commander-in-Chief with a laurel wreath, and at the same time she is blowing lustily on a trumpet and proclaiming to the world those immortal words, "Washington and Independence." On an altar is seated the Goddess of Liberty, who is contemplating a portrait of Baron Steuben. Two female figures are doing homage, one of them being in the act of burning incense on the altar.

The various heads on the medallions are faithful reproductions of the $\mathrm{Du}$ Simitiere series of portraits of well-known Revolutionary leaders. The originals of these prints are greatly prized by collectors.

There is another bed curtain print of the same early period, which is somewhat similar to the 


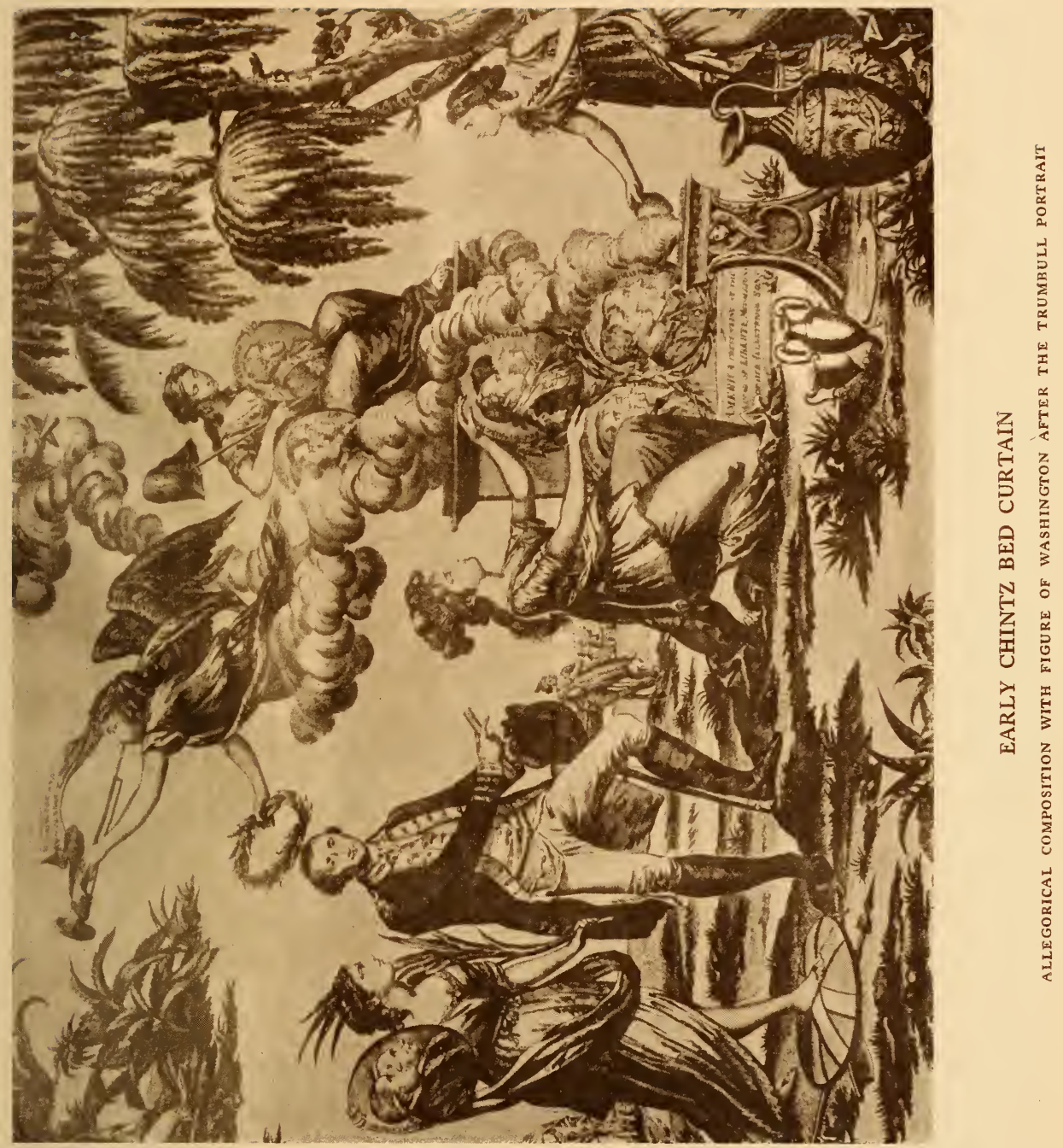



one illustrated. The figure of Washington is the same as that in the Trumbull portrait, with the exception that he is represented as wearing a military hat and is standing in a chariot drawn by tigers which are being urged forward by two Indian boys who are blowing on trumpets. Standing near the chariot is a full-length figure of the immortal Dr. Franklin in his inevitable fur cap. Minerva, armed with a shield adorned with thirteen stars, points out to the aged philosopher a temple of fame located in the background.

This portrait of Washington, owing to the many engravings which had been made of it, was perfectly well known to collectors and lovers of Washingtoniana; nevertheless for more than a hundred years the whereabouts of the portrait was entirely unknown, and all hope of ever discovering this interesting original had been abandoned when it was found in this city in the possession of a well-known art dealer, who had just brought it over from London, and it was quickly acquired by the present owner.

Whereas Gilbert Stuart will ever be known prominently as the portrait painter of the newly formed government, Trumbull will be known to posterity as the patriot painter of the Revolution. By tradition and early training and by 
the later course of his art studies, this proved to be the most natural development of his nature. Reared in an atmosphere of politics, an eye witness of the stirring events preceding the Revolution and with a father who was, of all the war governors, perhaps the most aggressive and who was known throughout the Colonies under the affectionate nickname which Washington himself applied to him, "Brother Jonathan," is it any wonder, when his son's facility in art work had matured, that he should have desired to perpetuate the stirring events of the War of Independence? In his autobiography, Trumbull devotes comparatively little space to his work in portraiture, but his main pride seems to rest upon his historical compositions. In fact, he painted comparatively few portraits but devoted his time principally to the great events of the war, which seemed particularly to fire his imagination. No one who has not visited the Art School at Yale University can form any conception of Trumbull's work. There may be seen the Battle of Bunker Hill, the Battle of Princeton, the Death of Montgomery, the Capture of the Hessians at Trenton, the surrender of Burgoyne and, last but not least, the Declaration of Independence. All of these are comparatively small pictures and 
should not be confounded with the large cartoons in the National Capitol, which were painted many years later. When the Capitol at Washington was being completed and the great dome was in course of erection, the idea was projected of decorating the wall of the rotunda with great historical paintings. Trumbull applied himself to the task of getting an appropriation from Congress for the carrying forward of this work. This resulted in his corresponding with a number of prominent people with reference to this project. The outcome of this correspondence was varied, and in many cases very discouraging to the artist. The following letter from President John Adams throws a curious side light on the primitive conditions of the times and upon the curious Puritanical point of view as regards the art development of the nation:

"My dear Sir:

“Quincy, January I, I 8 I 7 .

Your kind letter of the 26th of $\operatorname{Dec}^{r}$ has given me more pleasure than it would be prudent or decent for me to express.

"Your design has my cordial approbation and best wishes. But you will please to remember that the Burin and the Pencil, the Chisel and the Trowell have in all ages and Countries of which we have information been enlisted on the side of Despotism and Supersti- 
tion. I should have said Superstition and Despotism, for Superstition is the first and Universal Cause of Despotism.

"Characters and Counsels and Actions merely social, merely civil, merely political, merely moral, are always neglected and forgotten. Architecture, Sculpture, Painting and Poetry have conspired against the Rights of Mankind and the Protestant Religion is now unpopular and odious because it is not friendly to the Fine Arts.

" I am not however a Disciple of Rousseau. Your Country ought to acknowledge itself more indebted to you than to any other artist who ever existed and I therefore heartily wish you success.

"But I must beg pardon of my Country, when I say that I see no disposition to celebrate or remember or even curiosity to enquire into the Characters, Actions or Events of the Revolution.

"I am therefore more inclined to despair, than to hope for your success in Congress though I wish it with all my heart.

"I should be glad to be informed of your progress, being with sincere esteem and real affection

\section{Your friend}

"Col. Trumbull."

John Adams."

Adams did not do justice, however, to the sense of patriotism of the representatives of the people, for not many months elapsed before Congress appropriated thirty-two thousand dollars for the 
carrying out of the work, and Trumbull was commissioned to paint four of the large canvases which now embellish the lower walls of the great rotunda.

Undoubtedly the best known, and deservedly so, of all these important pictures is the "Signing of the Declaration of Independence." Trumbull passed many years of his life in preparing the studies from life of the chief actors in this drama. For a very long time the picture remained unfinished, owing to the difficulty which he had in procuring portraits of some of the Signers. The original picture in the Yale Gallery is full of beauty and character. The large cartoon which hangs under the great dome of the National Capitol and which is the painting from which Trumbull's reputation is principally judged, is inferior to the earlier pictures in every particular. It was painted many years after the earlier composition was completed and not until long after Trumbull's skill as an artist had begun to wane. From an historical point of view the loss of this group, had it never been reproduced, would have been the most serious loss that could have come to the Nation artistically, for in this composition are preserved to posterity the portraits of the most distinguished statesmen of the revo- 
lutionary period, and the likenesses of very many of these men would have been irretrievably lost had it not been for Trumbull. Fortunately there is no danger now of such a calamity, as there are, besides the two paintings by Trumbull himself, the one at New Haven and the other at the Capitol, the admirable steel engraving by A. B. Durand. Owing to the reproductions which have been made, this notable picture is now familiar to every school boy in America. There is reproduced on another page a very curious corruption of this picture. It appears on an old lacquered tea-tray which was found in an antiquity shop in Shrewsbury, England, several years ago by a friend of the writer, and promptly purchased and sent to America. By comparing this composition with the well-known print, it will be observed that there are some distinct differences. It will be noticed that there are six figures instead of five standing before the desk of President John Hancock and also that the grouping is far different. Now what explanation can be offered for this variation from the original? It is hardly likely that the artisan who made the lacquered tea-tray did anything more than slavishly copy some design which was placed before him, nor is it reasonable to suppose that some 


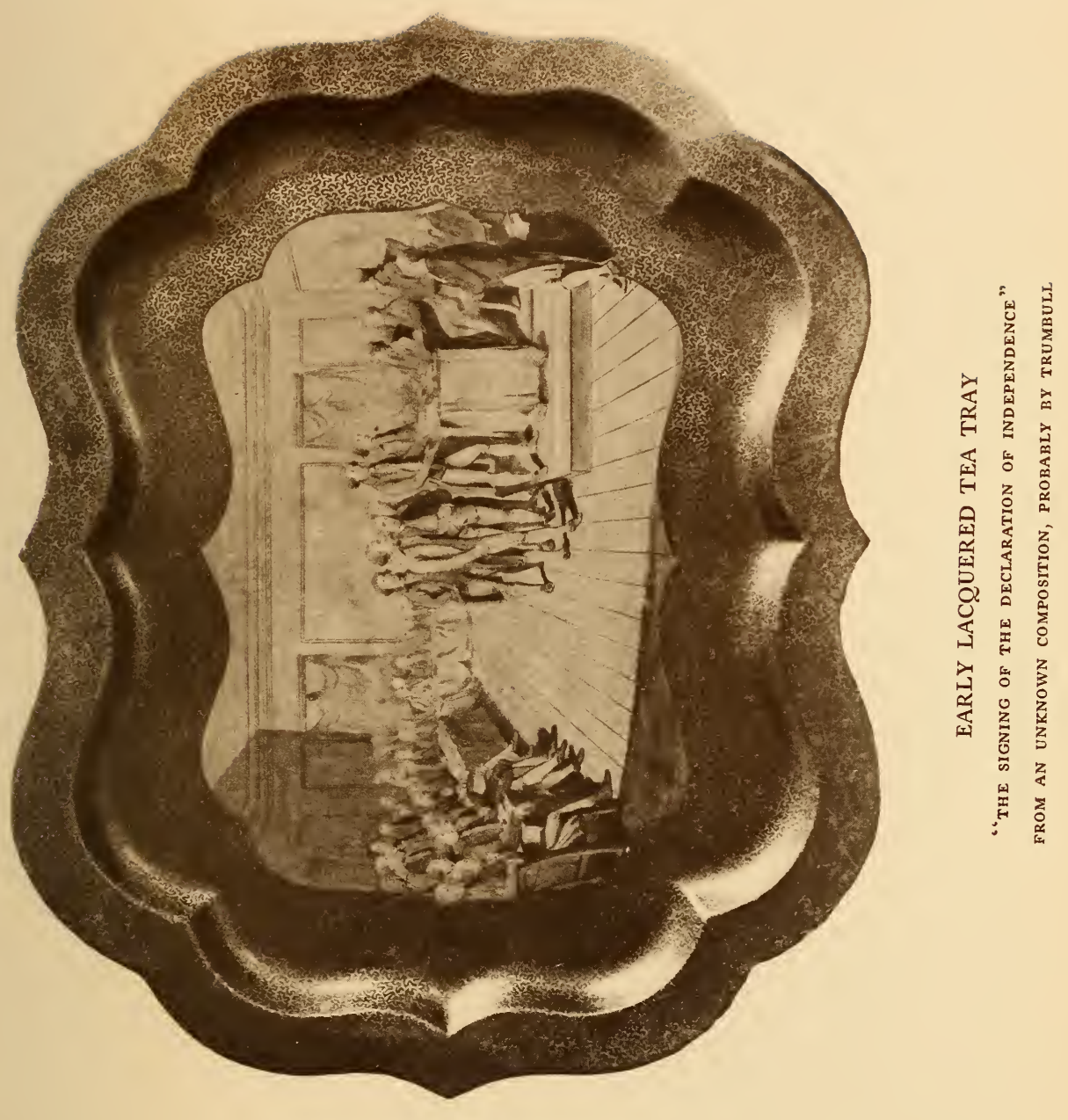





\section{JOHN TRUMBULL}

other artist was employed to alter in such minor respects the design of Trumbull. Such a practice was not followed in the case of other similar reproductions from celebrated paintings, as for example the views and scenes which have been reproduced so attractively on the Staffordshire blue china. Is it not more likely that the design was some original study which had been rejected by Trumbull but which, through some accident, fell into the hands of the tray-maker?

In the Library of Princeton University there are six preliminary studies of the Battle of Princeton, all of which vary materially in composition, but which in spirit are close cousins. It is doubtless true that Trumbull, who was a painstaking and laborious artist, followed a similar course with reference to the Declaration of Independence, and that one of these preliminary studies has been preserved in a manner which could hardly have been anticipated by the artist himself.

For the portraits which Trumbull introduced in these compositions he made small oil sketches from life of the distinguished actors in the dramas represented; these portraits were made in London, Paris, and in various parts of this country from Massachusetts to South Carolina. Some of his most charming productions are his por- 
traits and studies in miniature. They are not true miniatures, as they are painted in oils on wood, but they are full of character and individuality. Peale painted many miniatures, but they were painted in water colors on ivory.

These historical pieces never passed into private hands. Trumbull sought to gain his livelihood by having his principal pictures engraved, and these prints were offered for sale in this country and abroad. Trumbull's portraits are, therefore, of comparative rarity. There are only a few authenticated portraits of Washington by him, although probably there is no artist (not even excepting Peale) who had equal opportunities with Trumbull of limning the Father of his Country.

Besides the portrait described above, perhaps the most widely known portrait is the one representing Washington at the Battle of Trenton, which is now owned by Yale University. This was painted in 1792 . It is a large canvas and represents the Commander-in-Chief full length and life size, with a field glass in his right hand. At the rear is a horse held by an orderly and on the ground a dismantled cannon. This portrait was engraved by Thomas Cheesman and published in London August I, I 796. This engrav- 


\section{JOHN TRUMBULL}

ing is in stipple. The same picture was engraved in mezzotint by W. Warner and published in Philadelphia in 1845 . This portrait was originally painted for the City of Charleston, but the style of treatment was considered too martial and heroic and the portrait was rejected. Trumbull later painted another portrait for Charleston, but, judging from the print engraved in mezzotint and recently published by Rosenthal, the City was not the gainer by refusing the earlier portrait. An admirable, full-size copy, in oils, of the New Haven portrait has recently been hung in the Union Club, New York, having been presented to the Club by members who are Sons of the Revolution.

The next most important portrait is an imposing, full-length hanging in the Council Chamber of the City Hall in New York. It represents the Commander-in-Chief in full uniform, standing in front of the fort which was formerly located at the Battery, at the southern end of New York City. The Bay and Narrows may be seen in the background and the harbor is full of shipping. This important portrait has never been properly engraved. At the suggestion of the writer some years ago Mr. Arlent Edwards, the clever mezzotint engraver, whose color prints 
are so widely known, was induced to make a reproduction in mezzotint of the portrait, but he labored under great difficulties, as the room was dark and the picture could not be taken down, and so the result was not altogether satisfactory.

The only other important portrait of Washington by Trumbull is a full-length representation of the Commander-in-Chief in uniform, standing by the side of his grey charger. This closely resembles the portrait at the City Hall and evidently was a study for the larger picture. It was painted in 1790 and measures $20 \times 30$ inches and is therefore considerably smaller than the "de Neufville" portrait first described in this chapter. This picture belonged to General Edmund Law Rogers, of Baltimore and now belongs to the Rogers Estate.

Some idea of the intimate relations that existed between Washington and Trumbull may be gathered from the accompanying letter.

Copy of a letter from General Washington to the Marquis De La Fayette

My dear Sir:

“Philadelphia, Nov. 2 Ist, I79I.

Mr. John Trumbull with whom you are acquainted is engaged in painting a series of pic- 


\section{JOHN TRUMBULL}

tures of the most important events of the Revolution in this country from which he proposes to have plates engraved.

I have taken this peculiar satisfaction in giving every proper aid in my power to a subscription supporting this work, which has been likewise patronised by the principal people in this country.

In the hope of meeting the patronage of the French nation, to whose honor as well as that of America, this plan is directed, Mr. Trumbull informs me that he has ordered a subscription to be opened in Paris, and the object of this letter is to engage you to support the subscription in that City, and other parts of the Nation where it may be offered.

I should not however do justice to Mr. Trumbull's talents and merits were I to question his views and wishes on this occasion. His pieces so far as they are executed meet the warm applause of all who have seen them-the greatness of the design and the masterly execution of the work equally interest the man of a capacious mind, as the approving eye of the connoisseur. He has spared no pains in obtaining from the life the likeness of those characters, French as well as American, who bore a conspicuous part in our 
Revolution-and the success with which his efforts have been crowned will form no small part of the value of his pieces.

To you, my dear Sir, who know Mr. Trumbull as a man and as an artist, it would perhaps have been hardly necessary to say so much as I have done, on this occasion. But I could not in justice say less of him when I believe in his profession he will do much honor to the liberal art of painting as well as to this, his native country.

I cannot conclude this letter without congratulating you most sincerely on the King's acceptance of the Constitution presented to him by the National Assembly, and upon the happy consequences which promise to flow to your Country, as well as to mankind in general from that event. The prayers and wishes of the friends of the human race have attended the exertions of your Nation; and when your affairs shall be completely settled under an energetic and equal government the hearts of good men will be gratified, and no one will rejoice in your felicity, and for the noble and disinterested part you have acted, more than your sincere friend and truly affectionate servant

(Signed) Geo. Washington." 
The letter copied above, in Washington's handwriting, is in the possession of the writer and with it is a copy of the letter in the handwriting of Trumbull. Accompanying this copy is the following note in the handwriting of Trumbull, which is interesting as explaining why the letter of introduction was never delivered to La Fayette.

"This sheet covers, for the purpose of its preservation if possible, a letter written by Genl. Washington to the Marquis de La Fayette in I 79 I recommending to his protection in France the subscription of Mr. Trumbull's series of engravings intended to commemorate the great events of the American Revolution. This letter was written at the request of $\mathrm{Mr}$. $\mathrm{T}$. and sent by him to his correspondent in London (Mr. A. C. de Poggi) to be used in France. Unhappily, before the letter came to the hands of Mr. Poggi the French Revolution had begun to assume that character of bloody and inhuman ferocity which rendered it a curse and not a blessing to the human race, and when Mr. Trumbull accompanied Mr. Jay to London in 1797 it was returned to his hands." 


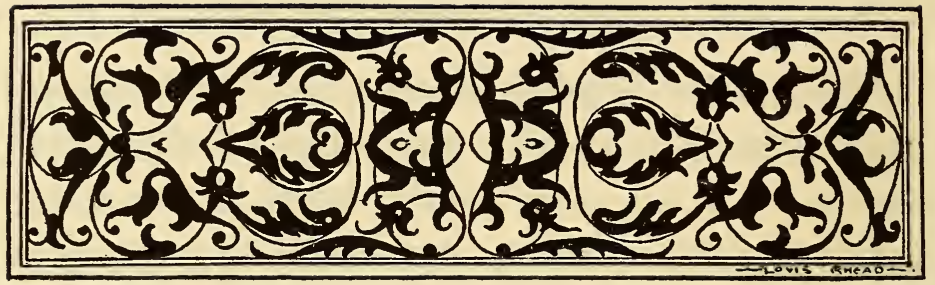

THE CHARLES WILLSON PEALE TYPE

$\mathbf{I}$

$\mathrm{N}$ the autumn of $\mathrm{I} 905$, while visiting a friend who is a Professor in Princeton University, ington, painted by Charles Willson Peale, which was offered for sale in Dublin, Ireland. Having obtained the address of the owner, a correspondence ensued, which extended over many months. After the credentials had been examined and satisfactory arrangements had been made, Mr. Roger E. Fry, Curator of Paintings of the Metropolitan Museum of Art of New York, who was about to sail for Europe, kindly consented to visit Dublin and examine the portrait. His report proved to be satisfactory, and the sale was finally confirmed by cable. The picture, carefully packed in a metal sarcophagus, arrived here safely in August, I 906, some ten months after the opening of negotiations. 
The portrait is an important one, the canvas measuring five feet two inches by seven feet.

A reproduction of the work is published opposite the title page. The Commander-in-Chief is represented as standing beside a field-piece, upon which he is resting his left hand. In his right hand he holds a hat and across his breast is the conventional blue sash which is often shown in the portraits of Washington painted by Peale. The British standards are lying in disorder on the ground, and overhead floats proudly the banner of the Colonies. In the background, at the left, is the college campus at Princeton, and some British prisoners in red coats are being marched across the field under guard. Grand old Nassau Hall, the largest building at that time in the Colonies, stands out distinctly in the background. The expression of the Commander-in-Chief is particularly pleasing and the painting has been much admired by those who have examined it.

The picture is carefully painted and the canvas is entirely untouched and clean and spotless, as when it left the easel. In all probability, the picture was painted between the years 1780 and 1783. The portrait of Washington hanging in the Faculty room of old Nassau, in Princeton, was painted in the latter year. 
As may be seen by examining the reproduction of the latter portrait on another page, the banner displayed over the head of the General is the stars and stripes. At first sight it seems as if the flag were composed of stripes alone, but a careful examination discloses one star and the intimation of a blue field. The banner of the Dublin portrait, however, is a plain blue field with a circle of thirteen stars - an earlier device. It would appear, therefore, that this portrait must have been painted earlier than the Princeton portrait.

Much interest centers in the question of the flag used during the early part of the war. Preble, in his " History of the Flag of the United States," says: "The portrait of Washington at the battle of Trenton, December 26-27, 1776, painted by Charles Willson Peale in 1779 , represents the Union Jack with thirteen stars arranged in a circle, but it affords only presumptive proof that such a flag was carried." Mr. Peale's son, Titian R. Peale, writing to a friend in I 870 , says: "I have just had time to visit the Smithsonian Institution to see the portrait of Washington painted by my father after the battle of Trenton. It is marked in his handwriting, I779. The flag represented a blue field 


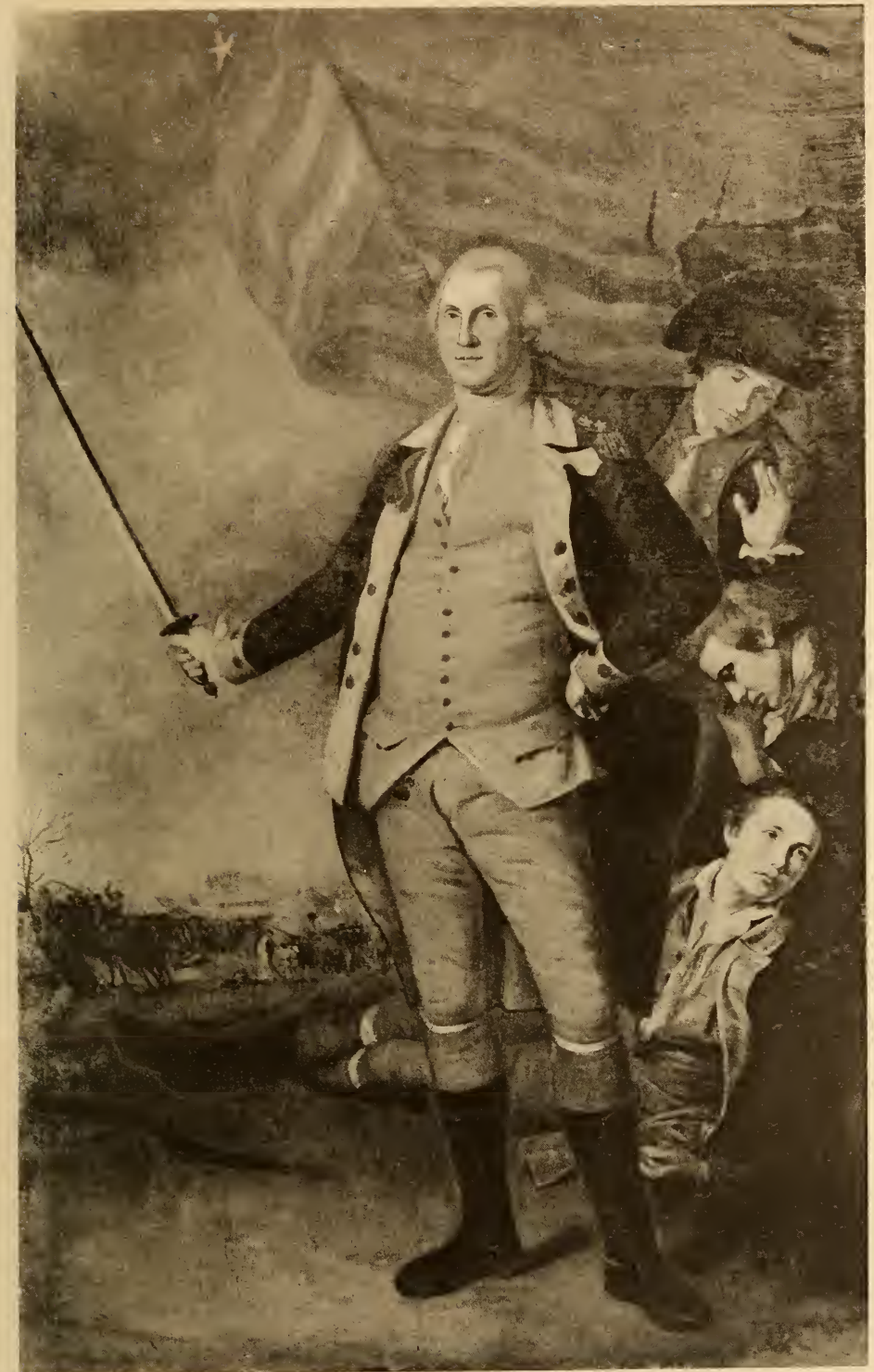

WASHINGTON AT THE BATTLE OF PRINCETON

PAINTED BY CHARLES W. PEALE-I78 3 

with white stars arranged in a circle. I don't know that I ever heard my father speak of that flag, but the trophies at Washington's feet I know he painted from the flags then captured, and which were left with him for that purpose. The blue ribbon has also excited comment the badge of a Field Marshal of France in that day.* I have no other authority, but feel assured that flag was the flag of our own army at

*The statement that the blue sash worn by Washington in this portrait and in other portraits of the Commander-in-Chief was the insignia of a Marshal of France was founded upon a very popular fallacy. When the army was encamped before Boston, owing to the absence in many cases of uniforms there was much confusion and difficulty in recognizing the person and rank of officers who might endeavor to pass the lines. In a MS. copy of General Washington's orders belonging to the writer is found the following entry:

"General orders.

Parole, Halifax.
Head Quarters, July I4th, I 775

Countersign, Inverness

There being something awkward as well as improper in the general officers being stopped at the outposts; ask'd for passes by the centinals \& obliged of ten to send for the officer of the guard who at sometimes is as unacquainted with the persons of the Generals as the privates before they can pass out or in, therefore it is Recommended to the officers and men to make themselves acquainted with all the officers in general command and in the meantime to prevent mistakes the general officers and their aid de camps to be distinguished in the following manner, the Commander-in-Chief a ligbt blue ribbon wore acrost his breast between his coat and waistcoat, the majors and brigadier generals by a pink ribbon wore in like manner, the aid de camps by a green ribbon." 
the time, I779. My father commanded a Company at the battles of Germantown, Trenton, Princeton and Monmouth, and I am sure represented the flag then in use, not a regimental flag, but one to mark the new Republic."

Preble further says: "I have been unable to find that it was ever required that the stars should be arranged in a circle, though in Trumbull's painting of the Surrender of Burgoyne and in Peale's portrait of Washington, the stars are arranged in that manner by those artists. The resolution of Congress of 1777 gives no direction as to the arrangement of the stars, but says they represent not Lyra, nor any heavenly cluster of stars, but a new constellation."

An unfinished sketch, of the battle of Princeton, by Trumbull, January 3 , I 777, in the Art School at New Haven, represents the American flag with thirteen stars on a blue field.

Peale, as intimated above, had served under Washington and was therefore perfectly familiar with the customs of war and the camp. He had made a careful study of military detail and possessed a solemn reverence for the events of the Revolution.

Although no record can be found of the blue flag with thirteen stars having been authorized 


\section{CHARLES WILLSON PEALE}

by Congress, it is hardly likely that this careful painter of the Revolution, should have represented a flag which was not in actual use by the army. Such a supposition is quite contrary to reason. The banners lying inverted at the left of Washington have been identified as colors captured from the Hessians at the battle of Trenton. In a book entitled "Regimental Colors in the War of the Revolution," by Gherardi Davis, there is quoted a letter written on December 31, I 776, by William Ellery, in which he describes with great accuracy the Hessian colors captured at Trenton. This letter absolutely confirms the statement made by Titian R. Peale that these standards were copied from the originals, and it is a wonderful tribute to the care and accuracy of Peale's work that the detail shown in these flags corresponds exactly with Mr. Ellery's description.

It is interesting in this connection to compare this portrait with the engraving which is considered by collectors in many respects the most prized of all the portraits of the General. It is the first engraved portrait of Washington published in this country. This portrait was engraved in mezzotinto by Charles Willson Peale after a portrait by himself, painted for Governor Hancock. In a paper read by William S. Baker, 
the pioneer student of Washington portraiture, before the Pennsylvania Historical Society in I 889 , allusion is made to the existence of this print. He says that the first engraved portrait was executed in 1778 . "From this plate, however, no impressions are known, the information as to its production being obtained from his manuscript note book as follows: 'Oct. 16, 1778. Began a drawing in order to make a mezzotinto of Genl. Washington. Got a plate of Mr. Brooks, and in pay I am to give him 20 of the prints in the first 100 struck off. Nov. I 5 th. Began to print off the small plate of Genl. Washington. I 6th, Continued the same business all day and sold I I doz. at Five Doll's." " What would not this veteran collector and student have given to have seen and owned one of these rarities! It was fifteen years after this before one of these prints was discovered and given out to the world in the admirable Catalogue of Washington Portraits, issued by the Grolier Club in 1904 . The only title on the print is that shown in the reproduction: "His Excellency, George Washington, Esqr." Mr. Charles Henry Hart, the able Editor of this work, says in his preface: "Perhaps the most important find recorded in these pages is the first number of the book, Charles Willson 


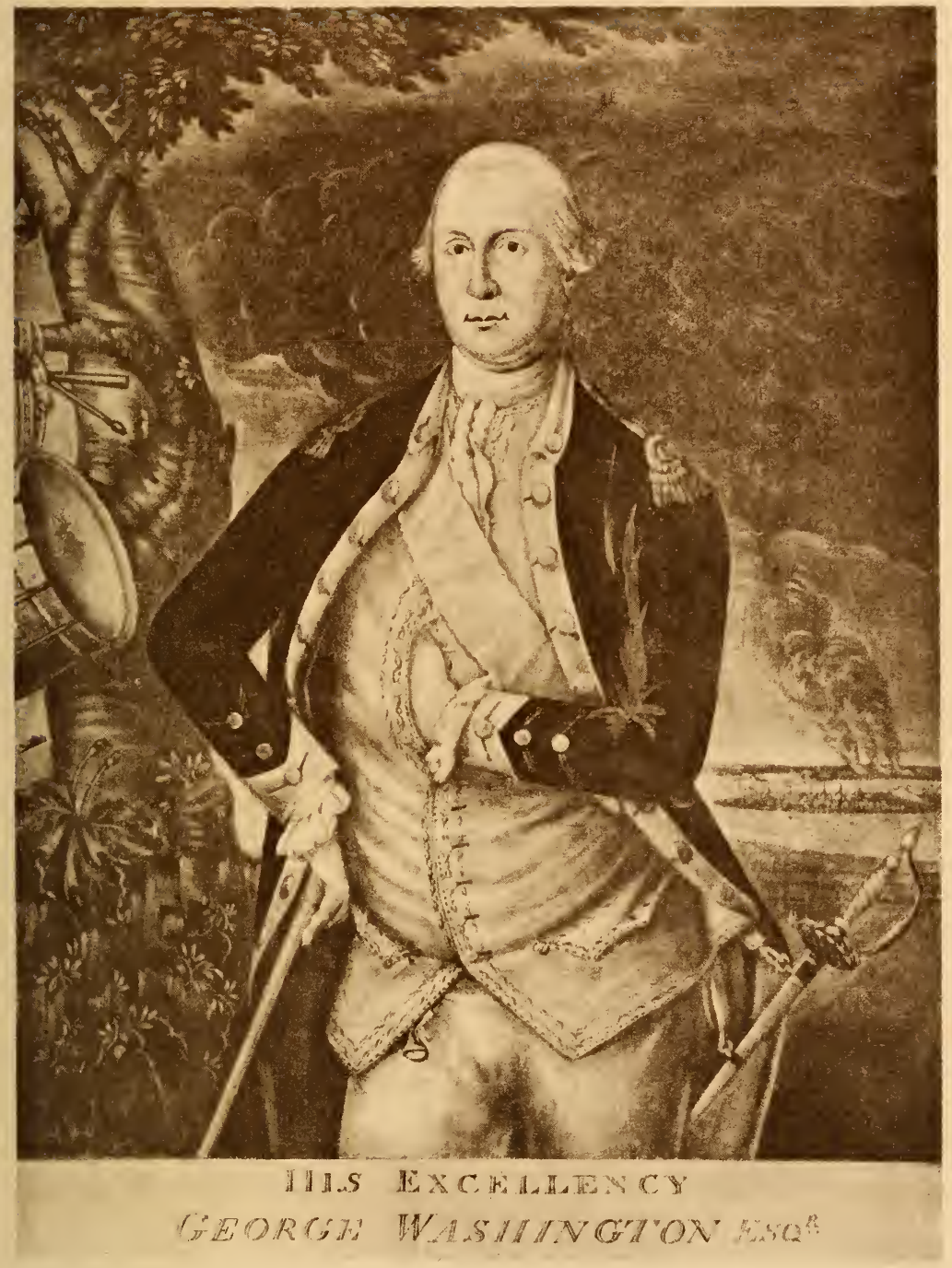

EARLIEST AUTHENTIC ENGRAVED PORTRAIT OF GENERAL WASHINGTON DRAWN AND ENGRAVEd By C. W. PEALE, I778 

Peale's earliest mezzotint portrait of Washington, published in 1778 and which, until my discovery, was thought not to exist, being known only by its advertisement." The advertisement alluded to appeared in the Pennsylvania Packet or General Advertiser, for Saturday, November $2 \mathrm{I}, \mathrm{I} 778$, and mentions the print as on sale by John Dunlap, at the price of five dollars, and reads: "A few mezzotint prints of His Excellency, General Washington." As an engraving it is a crude piece of work. As a work of art it is singularly deficient. The pose is awkward and theatrical, and the drawing leaves everything to be desired; but in spite of these crudities this youthful face bears a striking resemblance to the Washington in the Dublin portrait. To the heart of the collector this print, with all its amateurish peculiarities, will always have a special charm and attraction as being the first medium by which an admiring public learned to know anything concerning the physical appearance of the Commander-in-Chief. It seems singular and is a conclusive evidence of the primitive condition of art in those days that three years elapsed after the breaking out of the war before a portrait should have been published of the man who was the most admired and esteemed of men 
by his fellow-countrymen, and whose fame had extended to the most remote parts of Europe.

The youthful Washington of the period of the Revolution is a type, strange to say, which seems to be comparatively unknown to the ordinary layman, whose only idea of the Father of his Country is that portrayed in the Stuart portraits. It is interesting, therefore, in this connection, to compare the type disclosed in the Dublin portrait with the head shown in the Trumbull portrait previously described, which was painted about the same period. The resemblance between the two is certainly very striking. Peale had singular opportunities for making studies and portraits of the Commander-in-Chief, and there is no doubt that he painted more portraits of the General from life than any other artist. Mr. W. S. Baker, in his pioneer work on the engraved portraits of Washington, states that Peale painted fourteen portraits of Washington from life. It has not been claimed that Trumbull painted more than three from life, nor is it likely that Stuart painted more than that same number from life, although it would seem that he must have had an opportunity of touching up some of his copies while he had the President in his studio for some of his sittings. 



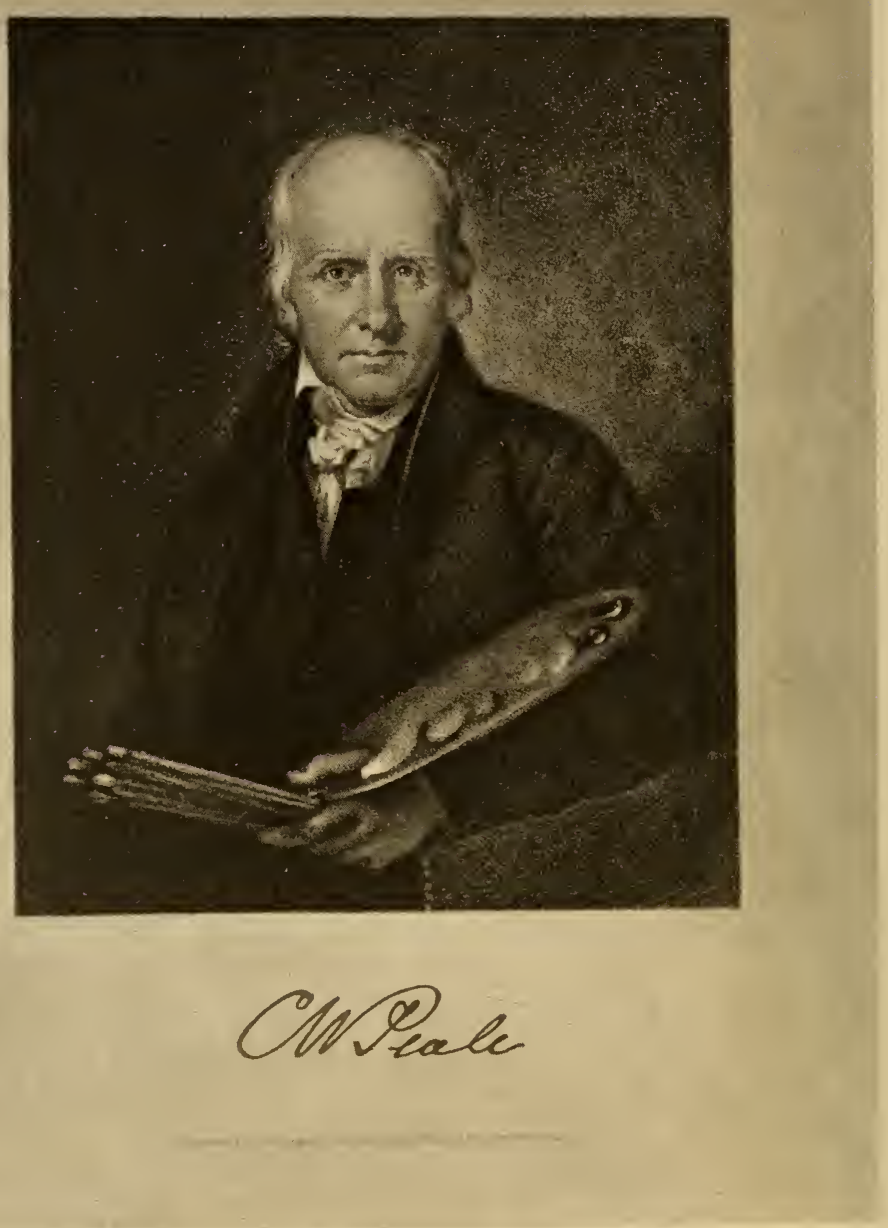

CHARLES WILLSON PEALE

FROM THE NATIONAL PORTRAIT GALLERY 
There is a most interesting similarity in the careers of Trumbull and Peale. Although Peale was fifteen years the senior of Trumbull, they both went to Boston to study art, and both of them applied to Copley for assistance or advice. Both served in the War of the Revolution and both attained some prominence. Peale reached the rank of Captain of Volunteers and Trumbull served as Aide-de-Camp to Washington, and later was appointed Major of Brigade and finally reached the rank of Colonel. Both went to London to study painting under their fellowcountryman, Benjamin West. When they returned to their native land, after their studies abroad had been completed, both were interested in establishing art schools in their adopted cities. Trumbull was a leading spirit in and became the President of the New York Academy of Fine Arts, the predecessor of the Academy of Design, while Peale attempted to form an Academy of Fine Arts in Philadelphia. Both devoted their artistic talents principally to painting the portraits of men prominently connected with the Revolution and with the infant government. Their line of work, however, was along somewhat different channels, for although Peale devoted himself entirely to portraiture, 
Trumbull became the pictorial historian of the Revolution. Of the two men, Peale had the greater versatility, and his many accomplishments are the subject of considerable mirth at the hands of that ribald chronicler and critic, William Dunlap. In his "History of the Arts of Design" he says: "We shall sum up the trades, employments and professions of Mr. Peale somewhat as his biographer in the Cabinet of National History has done. He was a saddler, harness maker, clock and watch maker, silversmith, painter in oils, crayons and miniature, modeler in clay, wax and plaster; he sawed his own ivory for his miniatures, moulded the glasses and made shagreen cases; he was a soldier, a legislator, a preserver of animals, whose deficiencies he supplied by means of glass eyes and artificial limbs; he was a dentist, and he was, as his biographer truly says, a mild, benevolent and good man." Dunlap neglected to mention in his list the fact that Peale was an engraver in mezzotinto (an art little practiced in this country at that time) of no mean ability. Owing to their intrinsic interest and great rarity Peale's mezzotints sell for more to-day than Peale received during his lifetime for his original portraits. $\mathrm{He}$ died in 1827 , in the eighty-sixth year of his age. 

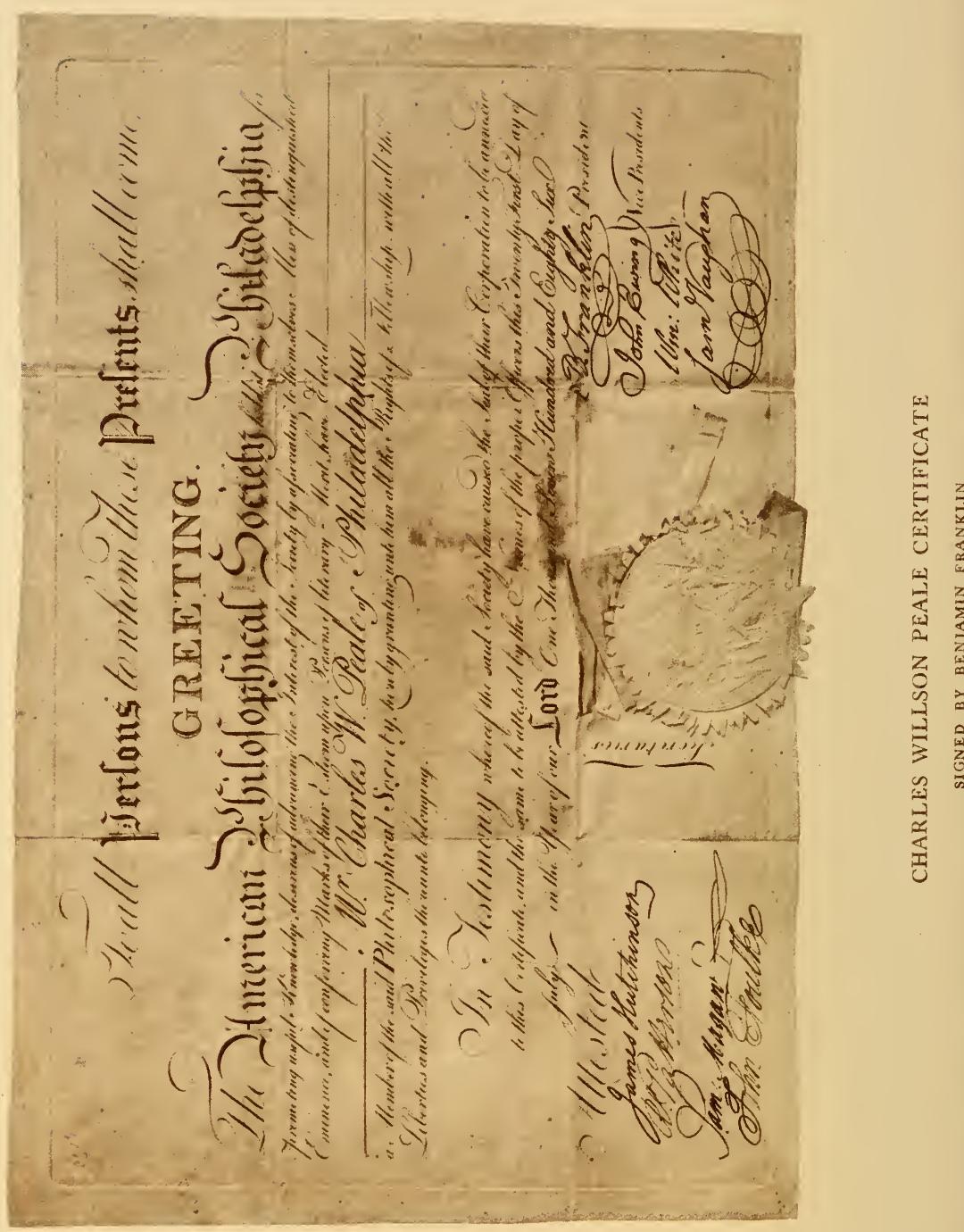
Trumbull died in 1843 , in the eighty-seventh year of his age.

HISTORY OF THE PEALE PORTRAIT OF WASHINGTON

The portrait was purchased, as stated above, in 1906, from James Harrington Wilson, of South Hill, Clifden, County of Galway, Ireland. The following is the history of the portrait as given by the late owner, the original of which, is in the possession of the present owner of the portrait, together with all the other papers referred to hereinafter, including the commission to the original owner, Joseph Wilson, signed by George Washington, President, and the commission issued to his son, Thomas Wilson, and signed by John Quincy Adams, President.

STATEMENT OF JAMES H. WILSON

County of Galway $\{$ I, James Harrington WilTo wit $\}$ son, of South Hill, Clifden, in the County of Galway, and of Armagh, in the County of Armagh, esquire, do solemnly and sincerely declare as follows:

I. THAT my paternal great-grandfather was Joseph Wilson, formerly of Philadelphia in the United States of America and of the City of Dublin, merchant.

2. THAT my said great-grandfather was owner of estates in the County of Armagh to which I have suc- 
ceeded as heir under settlements made by the settlements and wills of my said great-grandfather Joseph Wilson and my grandfather Thomas Wilson.

3. THAT I have since the death of my father Joseph Wilson, been in possession of the said estates and as such became the owner, and have been in possession of the portrait of General George Washington hereafter referred to.

4. MY said great-grandfather Joseph Wilson resided in, and was a merchant of considerable standing in the City of Philadelphia, and at the time of his death was the owner of considerable property in the City of Philadelphia adjoining the River Delaware, and also a man of great wealth and owner of property in Ireland and from the repute in my family he was Aid-deCamp to General George Washington, the first President of the United States of America during the War of Independence, and a great personal friend of his.

5. WHEN my said great-grandfather came to reside in Dublin he was appointed Consul for the United States, and I refer to the original Patent of his appointment as such Consul which is dated the 29th day of May 1794 and signed by George Washington and the Secretary of State of the United States of America, and on which marked "A" I have signed my name before making this Declaration.

6. IT IS THE reputation in my family that the full-length picture of General George Washington was a presentation to my said great-grandfather from the said General Washington, and that to prove his grati- 
tude to my said great-grandfather the said General Washington stood for the picture and had it painted for him, and my said great-grandfather Joseph Wilson by his will bequeathed the picture as an heirloom to his son Thomas Wilson. My said great-grandfather's will is dated the I $3^{\text {th }}$ day of February, I 809 and I refer to an official certified copy of extracts from same on which marked "B" I have signed my name before making this Declaration.

7. MY GRANDFATHER the said Thomas Wilson who succeeded to the said estates and possession of the said picture was also appointed Consul for the United States of America at Dublin, and I refer to the original Patent of his appointment signed by President John Quincy Adams and dated the I 7 th day of March I 826, and countersigned by H. Clay, Secretary of State for the United States of America, on which marked "C" I have signed my name before making this Declaration.

8. MY GRANDFATHER the said Thomas Wilson bequeathed the said picture of General Washington to his son my father Joseph Wilson also to go as an heirloom with the family estates, and I refer to an official copy extract from the will of my said grandfather Thomas Wilson which is dated the $15^{\text {th }}$ day of April I 857, and on which marked " D" I have signed my name before making this Declaration.

9. MY FATHER the said Joseph Wilson succeeded to the family estates and to possession of the picture of General Washington, and by his will my said father bequeathed the said picture to the Trustees of 
his will to go upon the trusts of the family real estates in the County of Armagh as contained in the will of his late father Thomas Wilson. I refer to an official copy extract from the will of my said father Joseph Wilson dated 27 th day of July I 898 on which marked "E" I have signed my name before making this Declaration.

ı. MY SAID FATHER Joseph Wilson died on the $27^{\text {th }}$ day of July 1898 and on his death I went into possession of the said family estates and into possession of the picture of the said General Washington, and I became owner of the said family estates in the County of Armagh as tenant in tail in possession and as such tenant in tail in possession I became absolute owner at law of the said picture.

II. I DULY disentailed the said family estates and am now the absolute owner thereof as well as of the said picture.

12. THE picture of General Washington which I now refer to, and which is at present in my solicitors' office at 10 Ely Place in Dublin is the original picture which belonged to my great-grandfather Joseph Wilson, and which has remained in my family ever since, and I say that the said picture was greatly valued and esteemed as a painting from life of the said General Washington by my said great-grandfather, grandfather and father as a memorial of the personal friendship of my great-grandfather Joseph Wilson with the said General Washington.

And I make this solemn declaration conscientiously believing the same to be true and by virtue of the 
Statutory Declarations Act I 835 (5 and 6 William IV) Cap 62

James H. Wilson

Made and subscribed before me this 20 th day of June, 1906.

John J. King, Commr. for oaths.

COPY OF THE WILL OF JOSEPH WILSON, DATED FEBRUARY I 3, I 809

In the name of God. Amen. I Joseph Wilson formerly residing at Philadelphia in the United States of America now of the city of Dublin Merchant.... make this as my last will and testament hereby revoking all former will or wills by me heretofore made. . I also hereby devise to my said son Thomas Wilson all my printed Books together with my watch and fire arms and my whole length picture of General $W$ ashington which picture I desire may remain to him and his heirs as an Heir loom but in case my said son Thomas should not live to attain the age of Twenty two years or not leave lawful issue then the foregoing bequests to the use and benefit of my son Robert Wilson but in case he should not live to attain the age of Twenty two years or not leave lawful issue then to my own right heirs.

COPY OF THE WILL OF THOMAS WILSON, DATED APRIL I 5, I 857

In the Name of God Amen I Thomas Wilson of Temple Street in the City of Dublin being of sound 
and disposing mind memory and understanding after first giving expression to my feelings of gratitude and thankfulness to that omnipotent Being who has watched over and protected me for such a number of years and after stating my firm and steadfast belief in the Divine Mission of His Son Our Lord and Saviour Jesus Christ declare this to be my last Will and Testament. ..... I also give and bequeath to my said wife for her own absolute use and benefit (save and except my picture of General Washington which I hereby specifically bequeath to my said son Joseph to the intent that so far as the rules of Law and equity will permit the same may go and be as an heir Loom) all my carriages and horses.......

\section{COPY OF THE WILL OF JOSEPH WILSON, DATED 1898}

I Joseph Wilson of Clonmore Stillorgan in the County of Dublin Esquire Deputy Lieutenant do hereby revoke all former wills and testamentary dispositions made by me and declare this to be my last will and testament.

I give and bequeath my picture of General Washington unto the Honorable Frederick Richard Falkiner Recorder of Dublin my son in law Frederick Coddington Pilkington my daughter Anne Elizabeth Savage and my Sons Joseph Reginald Wilson and Wilfred Claude Stanley Wilson their executors administrators and assigns upon such trusts as shall or may as nearly as the rules of law or equity will permit correspond with and be similar to the limitations of the real Estate 


\section{CHARLES WILLSON PEALE}

in the County of Armagh in Ireland contained in the said will of my late father, yet so that the said trust premises shall not for the effect or purpose of transmission vest absolutely in any person or persons who would be tenant or tenants in tail male or general by purchase under the said limitations contained in the said will of my late father who shall not live to attain the age of twenty-one years but the issue who would be inheritable under such limitations as aforesaid shall not be excluded I declare that the said Frederick Richard Falkiner, Frederick Coddington Pilkington, Ann Elizabeth Savage, Joseph Reginald Wilson and Wilfred Claude Stanley Wilson hereinafter called my trustees or trustee shall not be obliged to see to the preservation of my said picture of General Washington nor be answerable for the loss thereof or any injury thereto while in the possession of the person for the time being entitled to the possession thereof under the trusts hereinbefore declared concerning the said picture.

LETTER FROM MESSRS. BARRINGTON \& SON, SOLICITORS OF JAMES HARRINGTON WILSON

Dublin, July 28 th, 1906. re General Washington.

Dear Sir.

This picture was handed over to Mr. Strickland, and we understand that it has been packed and despatched by him to you, and we have received the purchase money from the Royal Bank of Ireland, Limited. 
We now send you, per registered post :-

(I) Original Patent signed by George Washington appointing Joseph Wilson Consul in Dublin.

(2) Original Patent signed by President Adams appointing Thomas Wilson Consul in Dublin.

(3) Official extracts from the will of Joseph Wilson, I 809 .

(4) Official extract from the will of Thomas Wilson, 1857 .

(5) Official extracts from will of Joseph Wilson, 1898.

(6) Original statutory Declaration of $\mathrm{Mr}^{-}$James Harrington Wilson giving the history of the picture.

We hope that the picture will arrive quite safely, and shall be glad to have an acknowledgment of receipt of these documents, and of the picture.

We are, dear Sir,

Yours very truly,

Barrington \& Son

Charles A. Munn, Esq.,

It will thus be seen that the connection between the present owner and the original proprietor is shown in a manner unusually complete, and that the portrait has never been out of the family of the original proprietor until the time of the sale to the present owner, in 1906.

Owing to Peale's unusual opportunities in campaigning with Washington and having his personal confidence, he was afforded more sittings of the Commander-in-Chief than any other 


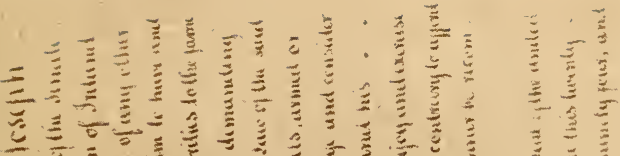

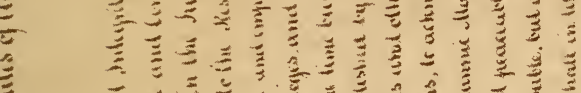

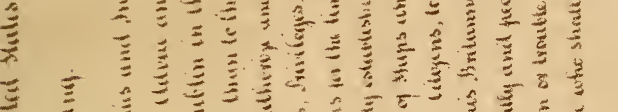

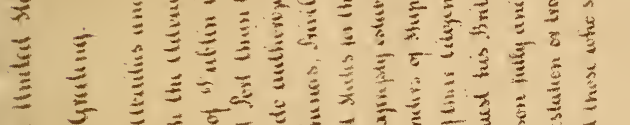

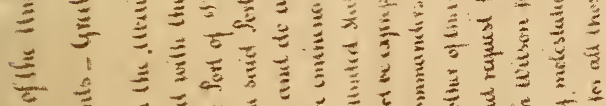

를

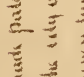

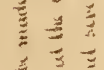

$\exists 0$

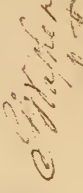

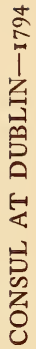

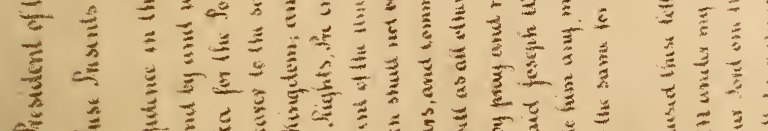

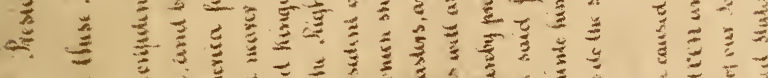

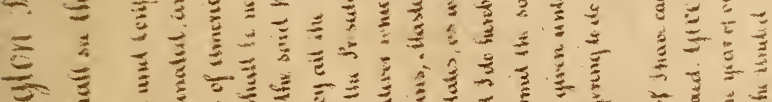

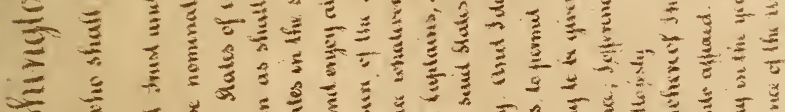

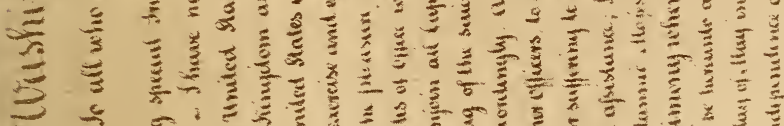

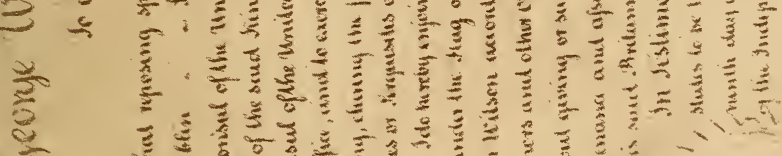

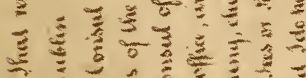

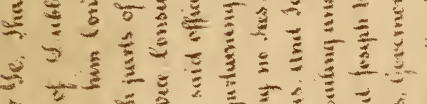

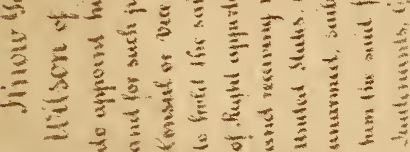



painter ever enjoyed. In addition to the ones described above, namely, the Princeton and the Dublin portraits, there may be mentioned the one now hanging in the Capitol at Washington, which originally belonged to the Count de Menou. The Metropolitan Museum in New York owns a very fine copy, presented by the late C. $\mathrm{P}$. Huntington. There is an interesting one in Independence Hall, which was recently brought to this country from Spain. Mr. Thomas McKean, of Philadelphia, owns one, and there is one at Shirley, on the River James. There is one in the Palais at Versailles. The Earl of Albemarle owns a copy which was captured on the high seas by his ancestor, Captain Keppel. It now hangs in the great hall in Quiddenham Hall, Norfolk, England.

An extremely interesting portrait of Washington by Peale hangs in the State House at Annapolis. Like the others mentioned above, it is a full-length and in treatment and manner, as well as in the figure of the Commander-inChief, it strongly suggests the Princeton portrait, although it differs from it widely in composition. The special interest attaching to this portrait is that standing beside the central figure are the Marquis de La Fayette and Colonel 
Tench Tilghman. The head of the Marquis resembles a small head of this able young French officer which was engraved by Peale in oval form in mezzotint and which is greatly prized by collectors because of its intrinsic interest and its great rarity.

At the Chicago Exposition there was a portrait that appeared to have been painted by Peale. By some strange misconception it was attributed in the French catalogue to Trumbull. It belonged to Mme. de Pusy, of Paris, and formed part of the French Loan Exhibition of American Revolutionary relics. This attribution, however, is no more amusing than that given by Sir Walter Armstrong, Director of the National Gallery of Ireland and author of a work on Gainsborough and many other well-known books, who, after examining the Dublin portrait, gave a certificate to the effect that in his opinion the portrait was undoubtedly an original work of Gilbert Stuart. It is gratifying to feel that this charming portrait by Peale, after a sojourn abroad of over one hundred and ten years, should once again have returned to the Fatherland. 
.

\section{.}




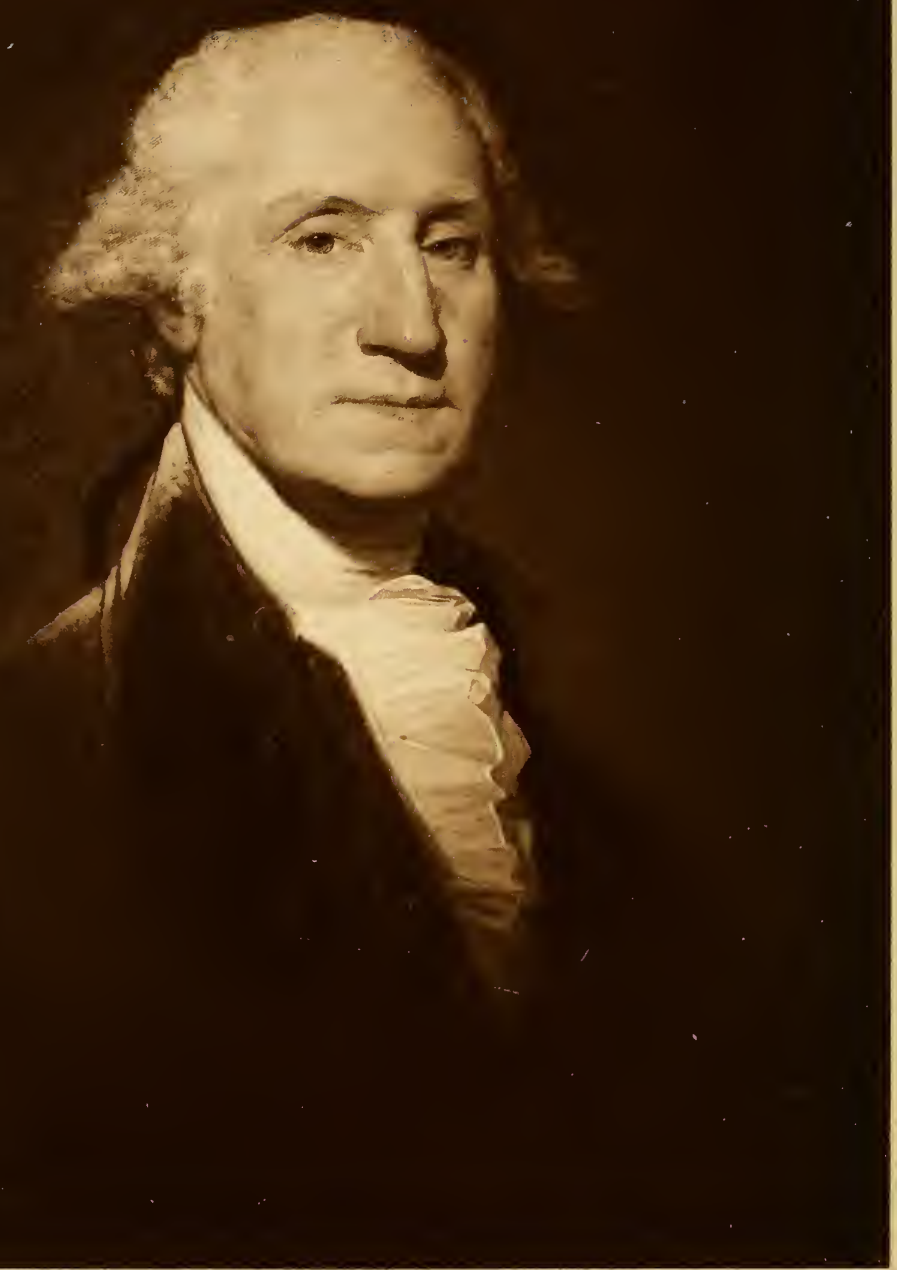

PRESIDENT WASHINGTON

PAINTED BY GILBERT STUART-I795

ORIGINAL OWNER

MR. SCOTT

PRESENT OWNER

CHARLES A. MUNN

OF LANCASTER, PA. 


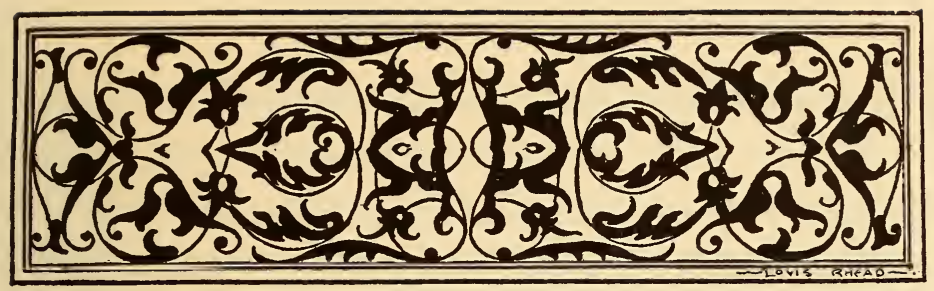

THE GILBERT STUART TYPE

T IKE Trumbull and Peale, Stuart went abroad at an early age to study art under Benjamin West. Born in 1755 , he sailed for England at the outbreak of the war in 1775 and thus, unlike these other artists, he saw no service during the Revolution. It seems strange that he should have tarried in London four years before presenting himself to West, but such seems to have been the case. $\mathrm{He}$ remained abroad seventeen years, during which time he painted many of the most distinguished people of the times, not the least of which were his master and Sir Joshua Reynolds. His portraits of these two brought him into great prominence and many of his portraits of important people were engraved by Valentine Green, J. R. Smith, W. Ward, Charles Turner and other of the leading engravers of the day. 
His ambition to paint the portrait of Washington is said to have been the principal cause of his return to his native land, in 1792 . It was not until I 794, however, that he proceeded to Philadelphia, armed with a letter of introduction to the President from John Jay, and the year I 795 was well advanced before the first sitting was arranged for. Stuart appears never to have enjoyed the same terms of intimacy with Washington that fell to the lot of either Trumbull or Peale. It has been said that he never was quite at ease with him who, without in the least meaning to do so, frequently overawed those with whom he came in contact. However this may be, Stuart did paint three portraits from life within the short period of a year. The Athenæum head he never finished and the tradition that it was left in this condition in order that he might retain it in his studio as a "nest egg" from which he could make copies is certainly pretty well substantiated. This charming portrait, together with the companion portrait of Mrs. Washington, was sold by his family after his death for $\$ 1500$ and given to the Boston Athenæum, and the fact that practically all the copies made by Stuart are from this picture shows how industriously he must have taken 
advantage of the opportunity presented by having this portrait ever before him.

Stuart died in 1828 and was buried in Boston Common. He was not only a very rapid but a prolific worker. At the exhibition of his portraits held in Boston in I 880 there was published a list of his portraits, and although this was not complete, it contained over seven hundred and fifty numbers.

The whereabouts of the various well-authenticated portraits of Washington by Stuart are for the most part pretty well known, but occasionally some portrait which is known to exist is lost sight of until, by some chance, it is rescued from obscurity. The most popular type of Washington portrait has ever been, not the Washington of the Revolution in a military uniform, but Washington, the President. Not the man of middle age with a comparatively young face, undisturbed by cares and anxieties, but the bewigged and powdered gentleman in a velvet coat and breeches and with a dress sword at his side. No man ever changed more in appearance than did Washington between the period of the Revolution and the time of his second administration as President, when he was sought after as a subject by the artists of America 
and by some who came across the seas to paint his portrait. The distinction of painting the great leader was considered one which added fame rather to the artist than to the subject.

In the interesting catalogue of " Engraved Portraits of Washington," published by the Grolier Club and edited by Mr. Charles Henry Hart, there are described sixty-six engravings of Washington after Charles Willson Peale portraits, fiftytwo after Trumbull, but there are enumerated four hundred and forty-one engravings after Stuart; in brief, there are nearly four times as many Stuart prints of Washington as there are of Peale and Trumbull combined.

The Stuart portraits have been cleverly classified for the convenience of collectors, into three main groups, known after the three principal originals which are recognized as having been painted from life. These are known as the Vaughan type, the Lansdowne type and the Athenæum type. Of these, by far the most popular, if we are to judge from the number of times the portrait has been engraved, is the last-mentioned portrait. From our childhood days we have all been brought up on that delightful, benign head with the unfinished background, called the Athenæum portrait. The Lans- 
downe type is less well known. Washington sat to Stuart for the original of this important fulllength portrait in 1796. The sitting was arranged for at the request of Mrs. Bingham, of Philadelphia, as the portrait was intended as a present for the Marquis of Lansdowne, after whom it has ever since been called. It is now in the possession of Lord Rosebery.

When this picture was finished and sent to London, the portrait was engraved by James Heath and published in 1800 without the knowledge or consent of the artist. It appears that Stuart had exacted a promise from Mr. Bingham that all rights of copyright should vest in him, but through some oversight the matter was neglected, and great was Stuart's wrath when he discovered these prints, by Heath, being offered for sale in Philadelphia. To add insult to injury, the engraver misspelled the artist's name and accredited the portrait to "Gabriel" Stuart. Miss Stuart states that this bitter subject could not be mentioned even in later years without her father's becoming greatly disturbed and pacing up and down the room in anger. The print possesses little artistic merit, but the artist felt he had suffered great pecuniary loss through the failure to obtain copyright protection. This led to 
an open rupture between Mr. and Mrs. Bingham and himself.

As far as his artistic sensibilities are concerned he need not have grieved greatly, as full justice was done to the picture in the following year, when Edward Savage, the most eminent and famous of American engravers in mezzotint, published a very handsome reproduction of the Lansdowne type. This is without doubt the most important mezzotint, both on account of size and subject and manner of treatment, of any that have been produced in this country. Unfortunately, this was engraved on a very soft piece of copper which very quickly wore out, so that to-day it is almost impossible to find a really fine impression of this important work. The two proofs which the writer has seen are very beautiful, and show the costume with such a soft surface, that it almost seems as if one could feel the warm surface of the velvet. The great importance of this print in a collection of Washington engravings seems never to have been appreciated. Not only is it entitled to a premier position as a specimen of mezzotint work which will bear comparison with the best mezzotints of England at a time when the art of engraving in this manner was at its height, but it is quite 


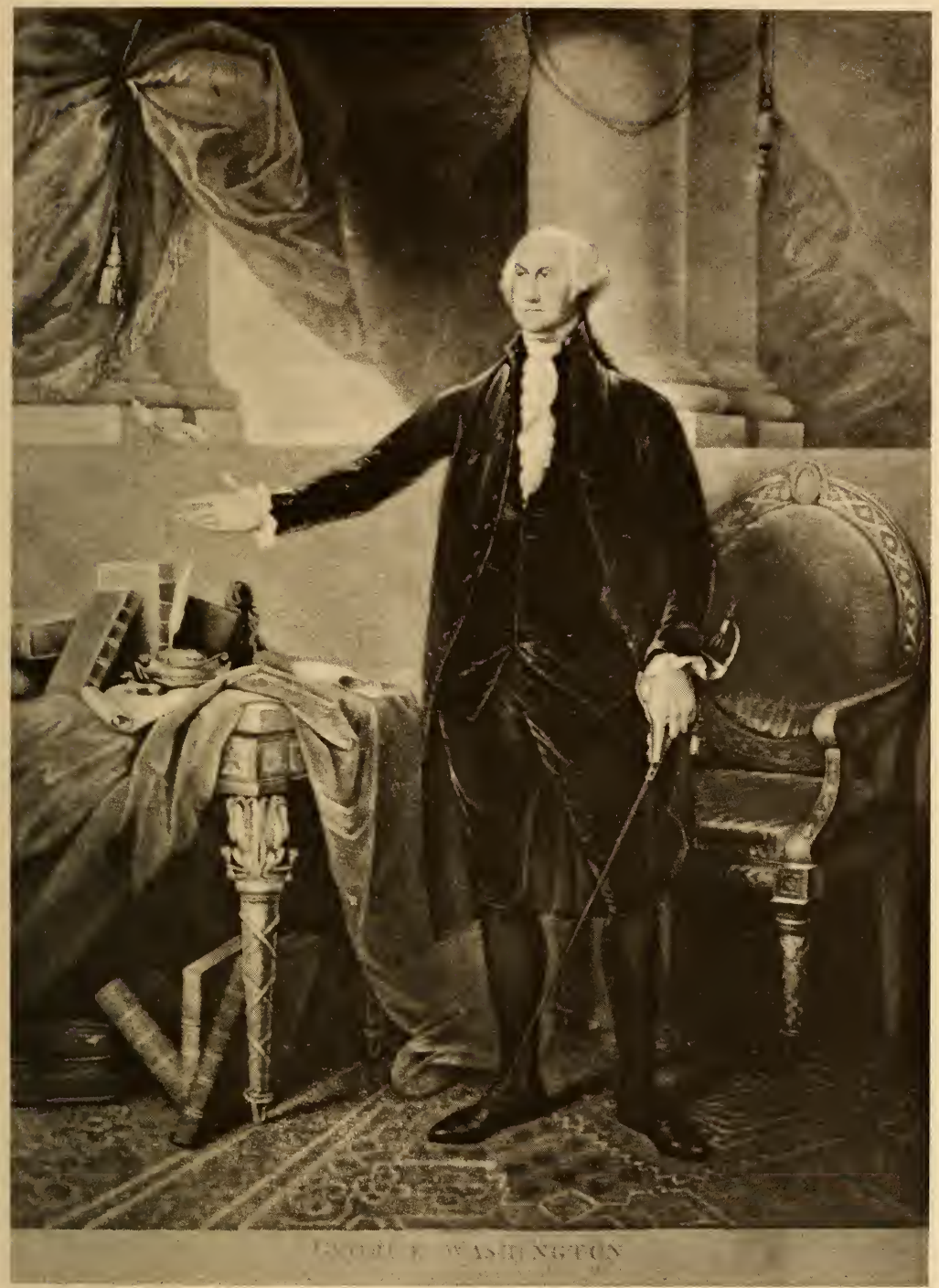

GEORGE WASHINGTON

ENGRAVED BY E. SAVAGE-I80I

AFTER THE LANSDOWNE PORTRAIT 

remarkable that a plate of this size could have been produced at all at that early day, in view of the undeveloped state of the art in this country at the beginning of the nineteenth century. The print measures twenty-seven inches in height and twenty and five-tenths inches in width.*

Edward Savage has never been accorded his rightful position as a mezzotint engraver of the first order. Not only was he an engraver in mezzotint and stipple, but he was an artist of considerable merit. His engravings were published towards the close of the eighteenth and beginning of the nineteenth century. As works of art they have never been rivaled or approached by any engraver in this country, and they will bear comparison with the work of the great contemporary masters in England. As in the Washington portrait, however, the plates were all very soft, and no fair estimate can be formed of his work unless proofs or very early impressions can be procured.

In the monumental work on the "American Engravers on Copper and Steel," edited and compiled by D. McN. Stauffer, and recently published by the Grolier Club, the author has reproduced *See Hart, No. 293. 
as a type of his work the small portrait of Washington by Savage, which is engraved in stipple. It seems unfortunate that one of the mezzotint plates of this master was not used as being more representative of the work of Savage. He was surpassed as a stipple engraver by both Tiebout and Longacre, but no one in this country ever surpassed him as a mezzotint engraver.

The second most important engraving of the Lansdowne type is also a very large print, measuring twenty-four and four-tenths inches in height and sixteen and one-tenth inches in width, by an unknown engraver and published the same year as the Savage print, viz., July I, I 80 I, by Atkins \& Nightingale, No. I 00 Chestnut Street, Philadelphia (Hart, 292). This print was published in black and in colors. A very beautiful impression of this mezzotint in proof state (before letters), printed in colors, brought the record price for a Washington print of $\$ 1,25^{\circ}$ at the sale of Judge Mitchell's collection, in 1906.

The earliest type of all, however, and the one which is now most admired by those who have made a study of the Washington portraits is known as the Vaughan type. It is so called because the first portrait ever painted of Washing- 
ton by Stuart was painted for Mr. Samuel Vaughan in September, I795. This portrait was sent to London, where Mr. Vaughan resided, and it was engraved by $\mathrm{T}$. Halloway and published in London, November 2, 1796 (Hart, 259). There is great uncertainty in regard to this portrait. In a letter written by Stuart when a very old man he makes the statement that the portrait painted for Mr. Vaughan was rubbed out by him, but later authorities have favored the theory that this was an error and that probably this portrait is the one now owned by Mrs. Joseph Harrison, of Philadelphia. The writer has not seen this original, but judging from a photographic reproduction it seems to lack the stamp of vigor and originality that are found in the Scott or the Gibbs-Channing portrait.

It is not now possible to assert positively which of these particular portraits is from life, but both the Scott and the Gibbs-Channing portraits possess so much quality that there is every reason to believe that in any event they must have received finishing touches while Washington was posing in the artist's studio. This type differs widely from the Athenæum type in that it represents Washington as a somewhat younger man and it is more pleasing, as it was painted 
THREE TYPES OF WASHINGTON PORTRAITS

before his features were disfigured by a bad fitting set of false teeth, which gave his mouth such a hard appearance, and which gives him an unpleasant expression in many of Stuart's portraits.

Although Stuart painted Washington again and again, according to Rembrandt Peale, he only painted six portraits of the Vaughan type, which shows the right and best side of Washington's head. "In the lower part of the face it has the advantage over the other portraits that he afterwards painted." These were all painted in 1795 , and they will be specifically mentioned later. In 1796 he painted the Lansdowne fulllength and soon after followed the Athenæum head.

George C. Mason, in his work entitled "The Life and Works of Gilbert Stuart," published I 879, says: "Stuart was overrun with orders for portraits from the moment that his picture of Washington was painted and although, as shown by the list he made out, he had heavy calls for copies of his likeness of the President, but few of them were at that time filled. When at length he began to meet this demand-and this was not till I796- his copies were all made from the picture known as the Athenæum head, which shows the left side of the head." This 


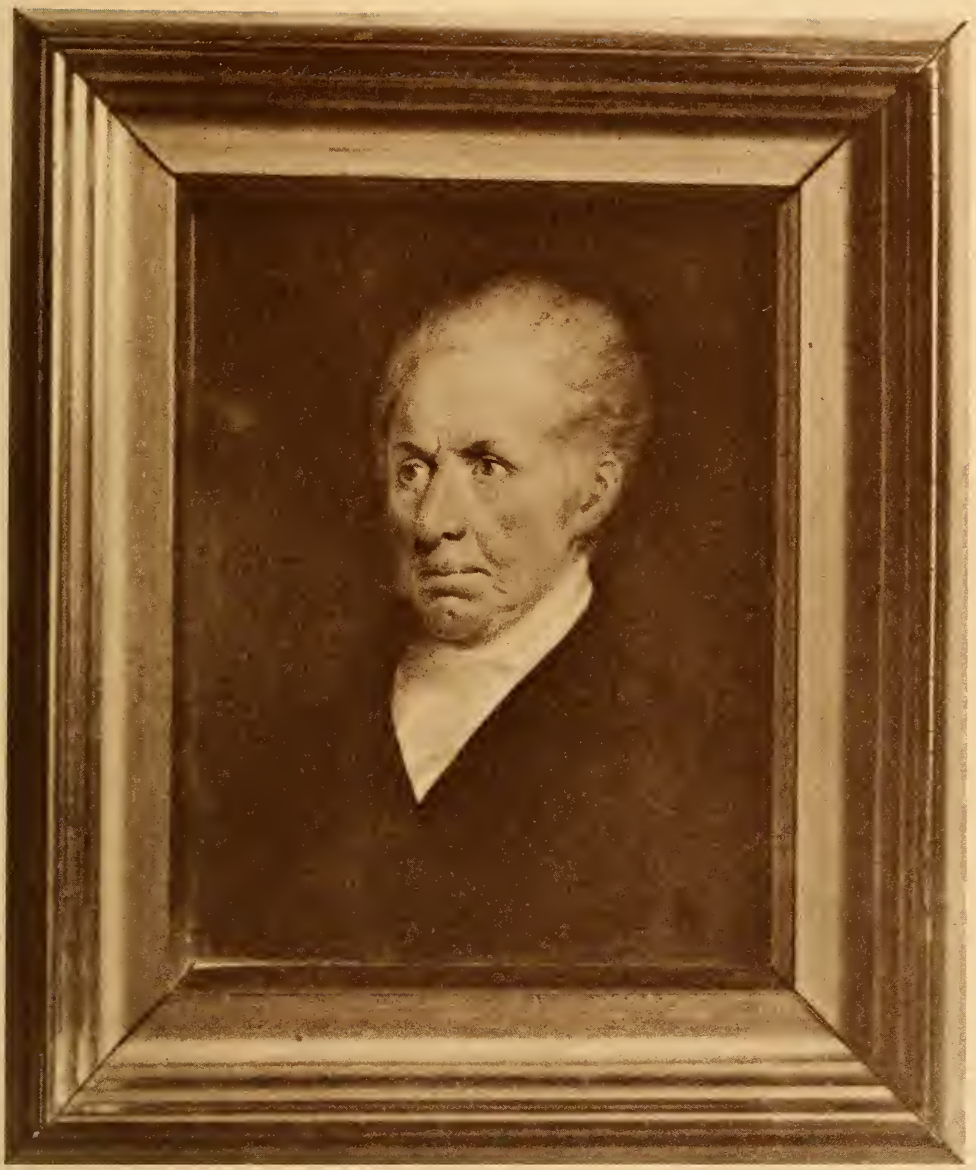

IVORY MINIATURE OF GILBERT STUART

PAINTED BY MISS GOODRIDGE

OWNED BY THE METROPOLITAN MUSEUM OF ART 

author also writes that the Washington portraits may be divided into two classes. "One shows the right side of the face-these are the earlier pictures, and the other, giving the left side, takes in all the portraits painted after April, I796the Lansdowne, Constable, Athenæum and other pictures that are generally known as 'Stuart's Washingtons.' It is very easy to establish the fact that the earlier portraits show only the right side of the face, but it is not possible to say now which of the earlier portraits is the earliest."

It will be interesting to enumerate briefly the portraits of the type which shows the right side of the head. Doubtless one of the most finished and beautiful of all is the so-called Gibbs-Channing portrait, which belonged to Mr. Samuel P. Avery, of New York, and which has just been purchased by the Metropolitan Museum of Art, where it is now on exhibition. The Museum is to be congratulated upon this notable acquisition. This portrait has a very clear pedigree. It was sold by Stuart at an early date to his warm personal friend, Colonel George Gibbs, and is claimed to have been touched up from life. Of this there is no proof, however, beyond the intrinsic merit of the portrait itself. Colonel Gibbs later sold the picture to his sister, Mrs. 
William Ellery Channing, who gave it to her son, Dr. William Q. Channing. Mr. Avery purchased the portrait from Dr. Channing. In a letter which Dr. Channing wrote Mr. Avery he makes the following comment, which may be said to apply equally to all the six portraits of this type: "The venerable A. B. Durand, when shown a photograph of it, said, "That is a likeness. It is much superior in character to the Athenæum portrait and should be considered the standard; both the artist and the subject would gain by it.' He also said he wished he could have known of it in earlier life, evidently meaning that he would have engraved it instead of the Athenæum portrait."

The canvas, however, which, in the admirable work on "Original Portraits of Washington," by Miss Elizabeth Bryant Johnston, published in I 882, receives with the Athenæum, Gibbs-Channing and Vaughan heads the most extended and flattering notice, is the portrait reproduced at the beginning of this chapter, and recently acquired by the writer. Its size is the standard Stuart size, $25 \times 30$ inches. After critical examination of this portrait, which belonged to Mrs. Anna R. Reilly, at present living near Trenton, N. J., this critic says: "It is painted upon twilled canvas, 
and the nails are also of the same kind that Stuart always used. The back-ground is a rich, dark red and the portrait, which was once on exhibition in New York, is described as being 'a solid work, the color good and portraying Washington as somewhat younger than in Stuart's other pictures.' It has never been engraved, but has been loaned to the New Haven Art School. This picture is another (the authoress has just described the Gibbs-Channing portrait) very beautiful reproduction of Stuart's first picture, and, as Mr. Peale says, the lines of the mouth are less objectionable than in the Athenæum portrait."

This portrait has a very complete pedigree, as may be seen from the accompanying letter from the late owner :

$$
\begin{aligned}
& \text { Trenton, N. J. } \\
& \text { March 3oth, I } 907 .
\end{aligned}
$$

Charles Allen Munn, Esq ${ }^{\mathrm{r}}$

\section{Dear Sir,}

The portrait of General Washington by Gilbert Stuart was purchased from the artist by Mr. Scott, of Lancaster, Penna., and was always considered one of the six original portraits.

Mr. Scott was well known to my family, and at his death, my grandfather, Edward Brien of Mattick Iron- 
works, Penna., bought the picture. My grandfather was married in $\mathbf{I} 805$, and the picture was purchased soon after. My grandfather died very suddenly in I 816 in his forty-seventh year. His family then removed to Lancaster, Penna., the portrait then becoming the property of my grandmother, Dorothy Brien. She was a daughter of General Edward Hand. About I 850 , the Historical Society of Baltimore wrote to her, and wanted to purchase the Stuart Washington. I was a young girl at that time, and I answered the letter, at my grandmother's dictation, and declined to sell. The picture has been exhibited at the Union League Club, the Art School in New Haven and in the gallery of A. T. Stewart. I have lived in the house with it, except on those occasions, all my life. In I 876, an article appeared in the "Century" [then called Scribner's Monthly] by Miss Stuart, the daughter of the artist, in which she stated that one of the most celebrated of her father's portraits could not be accounted for. Of course it was our picture and I was urged to write, and give an account of it. I was then in great affliction, and did not care to write. Miss Stuart urged the person who had the portrait to come forward. I am sorry now I did not do so. My husband, Mr. Edward Reilly, bought the picture from my mother.

After I became the owner of it I would not allow it to go out of my hands. We went to live in New York in $\mathrm{I} 88 \mathrm{I}$, and it was wanted for some celebration there but I refused to have it go. In I 879, a lady from Washington came to New Haven to see the picture, as she was writing a history of the Stuart portraits, and 
wanted to put it in her book.* It was then at the Art School. She climbed up a ladder to view it closely, and then asked permission to have it taken down for her to examine the canvas, as Stuart pictures were all painted on a certain canvas. She found the canvas all right. For the last seven years the portrait has been here. Since the death of my son-in-law, Mr. John Stockton Hough, I told my daughter Edith, who is my only remaining child, that I had left her the portrait in my will, and if she wished to sell it she had better do so during my lifetime, as I could tell all about it.

Prof. O. C. Marsh, of New Haven, asked a friend of mine to induce me to present the Washington to Yale. It seems that the six original pictures were four with the head one way and two the other. Our picture was one of the two. A gentleman in Phila. owns the other. He wrote to me about it and came to Trenton to see mine, but I was absent and missed him. Moreover, I have forgotten his name. Mr. Hough knew him. Only for Mr. Hough's violent and sudden death in 1890 , the portrait of Washington would not have been offered for sale. If I have omitted anything you wish to know, please write me.

Sincerely yours,
(Signed)
Anna R. Reilly.

In another letter Mrs. Reilly writes: "I have

* The lady referred to was evidently Miss Elizabeth Bryant Johnston, the author of that very interesting work, "Original Portraits of Washington," published by Messrs. Charles Scribner's Sons in 1882. 
lived in the house with that picture nearly all my life. I was brought up by my grandmother Brien and her two sisters, daughters of General Edward Hand, and all I know about its purchase I know from them. Mrs. Scott, the wife of the original owner, was godmother to one of my great-aunts. She (my aunt) lived to be ninety-four."

Among Stuart's papers was found a list of the portraits of the President of the United States for which he had already received orders. It is dated April 20, I795. In this list appears the name of Mr. Scott, of Lancaster, the original owner of this portrait and the person alluded to in the letter of Mrs. Reilly. Among others in this list are Mr. Vaughan, Benjamin West, President of the Royal Academy, Colonel Burr, of New York, Mr. Chief Justice Jay, Colonel Read and Don Jose de Jaudennes, who gave Stuart an order for five portraits of the President. This liberal patron of art will be recognized as the original of the beautiful portrait by Stuart which has recently ( 1907 ) been hung in the Metropolitan Museum, together with the charming portrait of his youthful American bride. One cannot help wondering if these five portraits were ever painted and if so, what has become of them. 
Another very charming portrait of this same type was illustrated in McClure's Magazine for February, 1897. This portrait belonged at that time to Mr. Charles Henry Hart, who later sold it to Mr. Marsden J. Perry, of Providence. Mr. Hart claims that this portrait was originally painted for Mrs. Bingham, through whose instrumentality the full-length portrait was painted and sent to the Marquis of Lansdowne. Mr. Hart, in his accompanying notes, says: "A duplicate of this portrait is owned by Mrs. Joseph Harrison, of Philadelphia, and these two are the only ones of this type known. The beautiful Gibbs-Channing portrait . . . is different." Mr. Hart was evidently unaware at that time of the portrait belonging to Mrs. Reilly and of the one belonging to Mr. Rives. It is indeed strange that of all the Stuart portraits of Washington extant, there should be only these few which are of the better type and show the nobler man. Mr. Hart says: "Until recently it was an unknown type to the general public, but it is gradually coming to the front, its proper place, and is being accepted as a more correct and real portrait of Washington than the familiar Athenæum head."

Another portrait, which belongs to the same type and period of I 795, belongs to Mr. George 
THREE TYPES OF WASHINGTON PORTRAITS

L. Rives, of New York. This portrait is almost exactly similar to the Scott portrait, having the same background of plain, deep red. It was inherited by $\mathrm{Mr}$. Rives from his father, $\mathrm{Mr}$. Francis Rives, who purchased it from Mrs. George Rives, of Sherwood, Albemarle County, Virginia. Mrs. Rives had inherited the portrait from her father, Professor Tucker, of the University of Virginia, the biographer and friend of Jefferson. It is not known how the portrait came into the possession of Professor Tucker.

For purposes of comparison there is reproduced a miniature on ivory painted by Robert Field. This miniature is of special interest as it contains at the back a lock of Washington's hair. This interesting heirloom was presented by Mrs. Washington to Tobias Lear, who for many years was Washington's secretary and trusted friend. It remained in the possession of the family until a few years ago, when it was acquired by the present owner.

Probably the best description which has yet been published of Gilbert Stuart's style of painting will be found in Samuel Isham's " History of American Painting," published by the Macmillan Co., New York, I 905 :

"Gilbert Stuart still holds his place among 


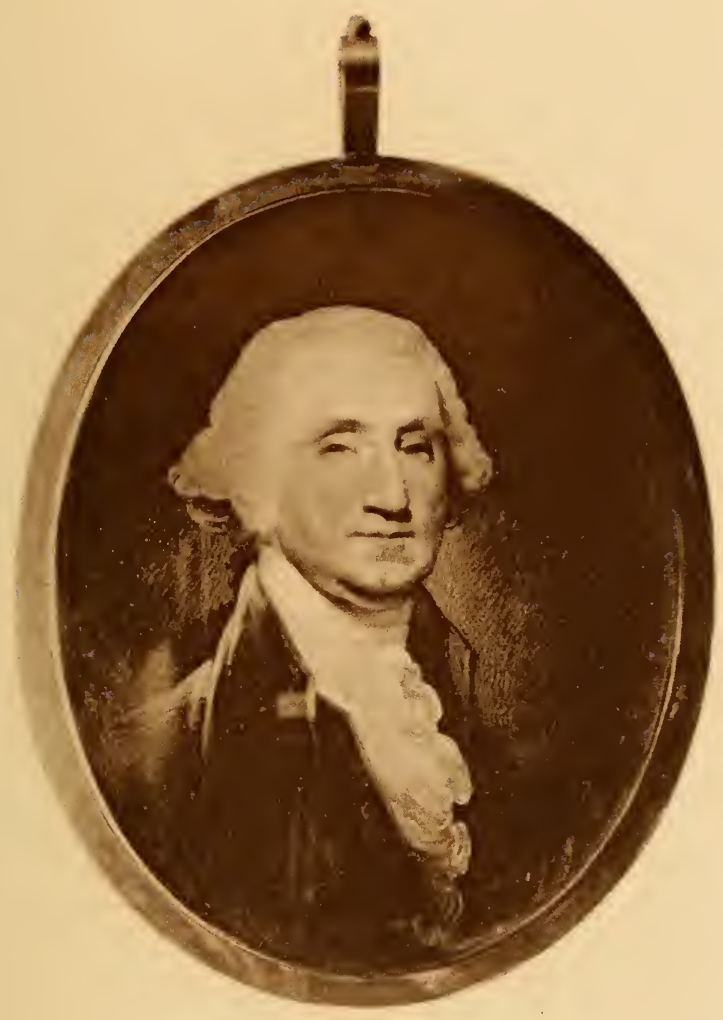

MINIATURE OF WASHINGTON

BY ROBERT FIELD

PRESENTED TO TOBIAS LEAR BY MRS. WASHINGTON 

our best painters, and even among his great contemporaries in England. His scope was limited. While they covered large canvases with fulllength figures and groups, using every aid of composition and costume to produce their effects, and showing the result of this practice even in the arrangement of their half-length portraits, Stuart painted heads and little besides heads, as far as known not a single group, a few fulllengths, more half-lengths, a large number of what used to be called Kit-Kats - canvases thirty by twenty-five inches - and many even smaller than that. The heads are placed near the center of the canvases, often so near it that the figure, which was painted in afterward, is cramped as it would not be if the head were higher. There is no effort to diversify the attitudes; and the costumes, while skilfully and sufficiently done, are but accessories to the heads, and there is no attempt to make them of important pictorial interest. The heads themselves are all painted in a cool, diffused light, seldom relieved by heavy shadows or dark backgrounds. There is nothing striking, nothing forced; it is only a heada head with its ordinary lighting and expression. No artifice is used to throw it into undue prominence. Within these limitations (and they are 
THREE TYPES OF WASHINGTON PORTRAITS

serious ones) they are unsurpassed. No one of his contemporaries had a surer feeling for the construction of a head or a surer insight into character. There are contradictory reports of his industry or indolence in studying drawing; but whether by industry or nature, he possessed it thoroughly, as far as the human features were concerned.

"Where he acquired his technique as a painter is even more mysterious. It seems to have been original with him. He could have got little teaching from Cosmo Alexander in Newport or in his erratic life before meeting West.

Exactly what the influence of his stay in West's studio was is difficult to determine; the obvious effects to be looked for he seems to have completely escaped. He got no taste for imitating the old masters, nor any liking for allegory, nor any skill in composition or in the handling of large canvases. Dunlap recognized their ' difference of opinion and style,' and in connection with it mentions the following circumstance which took place about 1786 on the occasion of a visit to his old master's house and gallery in Newman Street: 'Trumbull was painting on a portrait, and the writer literally lending bim a hand by sitting for it. Stuart came in, and his 
opinion was asked as to the coloring, which he gave very much in these words: 'Pretty well, pretty well, but more like our master's flesh than nature's. When Benny teaches the boys, he says, "Yellow and white there," and he makes a streak; "red and white there," another streak; "brown and red there for a warm shadow," another streak; "red and yellow there," another streak. But nature does not color in streaks. Look at my hand, see how the colors are mottled and mingled, yet all is clear as silver.'

"No better description of his own style can be given. He paints with an unequaled purity and freshness of color, very delicate and sure in the half-tones, varying his color to suit the individual, but with a pearly brightness which is characteristic. The paint is put on thinly, as a rule, in short, decided touches without heavy impasto, 'mingled and mottled,' as he himself says, and his execution was surprisingly sure. Two or three sittings sufficed for a head, which he painted at once in its true colors, distributing the paint as little as possible after it was on the canvas, and without resorting to the glazings and varnishings so much in vogue in England. This sureness of touch was the more remarkable because even in his youth Stuart's hand was trem- 
bling and unsteady; and in his later years, when some of his best work was done, an eye-witness says that 'his hand shook so that it seemed impossible that he could paint. The last time I saw him I think he was painting the portrait of Josiah Quincy (in I 824). Stuart stood with his wrist upon the rest, his hand vibrating, and, when it became tolerably steady, with a sudden dash of the brush he put the color on the canvas.'

"The brilliancy and preservation of his works to-day attest the soundness of his practice. $\mathrm{He}$ painted with a restricted palette which the curious may find in Dunlap and Mason, with his method of setting it; but let them not hope to produce the same results. Stuart's style was his own. He did not learn it from others, and though he gave advice freely and generously, he could not teach it to any successor."

In Mason's "Life of Stuart" above referred to, appears the following quotation from Miss Jane Stuart, the daughter of the great master. She says :

"I am frequently asked by young artists to give them some account of my father's method of painting; this I am quite willing to do, so far as my early recollection will permit; but I have not the presumption to attempt to explain his 
wonderful effects, which were peculiar to himself; nor do I believe they could be transmitted.

"The impression I have received from a study of Stuart's heads is that his success was due in a great measure to his wonderful perceptive faculties. As he was quick to read the character of a sitter, so had he a clear insight into the color of his complexion, and never was he known to fail in this particular.

" $\mathrm{He}$ commenced a portrait by drawing the head and features, and then he sketched in the general tone of the complexion; for this he seldom required more than four or five sittings, and frequently it was done in three sittings. The picture was never touched except when the sitter was in the chair. At the second sitting he introduced transparent flesh-tints, at the third he began to awaken it into life and give it expression, and then the individuality of the sitter came out. This was always done quickly. In the portraits of men advanced in life, where the roundness of youth is gone, we can almost fancy that he has given motion to the features. .. .

"It has been said by some critics that his coloring was too strong - that there was too great a preponderance of carnation in his flesh-tints; to this I cannot subscribe. Stuart did not rely 
on or require strong colors to produce his effects, for he had the faculty of bringing out his heads simply by the use of middle tints and tones, giving all the required rotundity and relief without the assistance of black shadows and heavy backgrounds; and yet the faces so painted are full of character and expression. In his work there is no appearance of labor, but everything that he did showed force and energy - so long as he kept to the head. When that was completed his enthusiasm seems to have abated. With some notable exceptions, the other parts of his pictures were painted but indifferently; but if he particularly fancied the subject, or the sitter was one in whom he took more than his usual interest, he worked with the greatest care to the end. In his draperies he was exceedingly careless, but he amused himself at times by painting lace, showing with a few bold touches of his pencil how easy it is to produce an effect when one understands what he is about. But if any one of his intimate friends took him to task for carelessness in rubbing in the accessories in a portrait, he at once replied, 'I copy the works of God, and leave clothes to tailors and mantuamakers." " 


. 



